\title{
Mulemba
}

Revista Angolana de Ciências Sociais

5 (10) | 2015

Angola 40 anos de independência: memória, identidades, cidadania e desenvolvimento

\section{Um álbum fotográfico da Diamang}

\author{
A photo album of Diamang
}

Diogo Ramada Curto

\section{(2) OpenEdition \\ Journals}

\section{Edição electrónica}

URL: http://journals.openedition.org/mulemba/1851

DOI: $10.4000 /$ mulemba.1851

ISSN: 2520-0305

Editora

Edições Pedago

\section{Edição impressa}

Data de publição: 1 novembro 2015

ISSN: 2182-6471

\section{Refêrencia eletrónica}

Diogo Ramada Curto, «Um álbum fotográfico da Diamang», Mulemba [Online], 5 (10) | 2015, posto online no dia 11 outubro 2018, consultado o 26 janeiro 2021. URL: http://journals.openedition.org/ mulemba/1851 ; DOl: https://doi.org/10.4000/mulemba.1851 


\title{
Um álbum fotográfico da Diamang*
}

\author{
Diogo Ramada Curto ${ }^{* *}$
}

\begin{abstract}
Resumo: Flagrantes da vida na Lunda (1958) de José Osório de Oliveira, um álbum fotográfico encomendado pela Companhia dos Diamantes (Diamang), é o ponto de partida para uma discussão sobre a ideologia colonial. Seguindo e discutindo o método descritivo a que os antropólogos recorrem, a abordagem proposta mobiliza um arquivo compósito, do qual fazem parte, diversas fontes e séries documentais. De igual modo, os argumentos de natureza analítica são formulados, tendo em conta a necessidade de distinguir entre o estatuto das representações, produzidas com a intenção de extrair delas um efeito legitimador da exploração do trabalho, e os interesses económicos e políticos por parte dos que mais podiam decidir. No conjunto, trata-se de uma descrição densa, mas capaz de pôr em causa as perspectivas demasiado atentas aos aspectos culturais e estéticos do colonialismo, que acabam por marginalizar os aspectos políticos e económicos.
\end{abstract}

Palavras-chave: Ideologia colonial, fotografia, destribalização, Lunda, Companhia dos Diamantes, trabalho forçado-escravatura moderna.

Desde a década de 1990, têm-se multiplicado os contributos de antropólogos portugueses para a análise histórica das ideologias e das instituições coloniais. Reconhecer o carácter decisivo de tais contribuições, ancoradas numa disciplina que não é a minha, afigura-se um acto de justiça, mas também uma fonte de inspiração. A capacidade de concentração em objectos concretos, a aplicação do

* O texto do presente artigo foi inicialmente apresentado em Luanda, na Sala 205 (edifício 1) da Faculdade de Ciências Sociais (FCS) da Universidade Agostinho Neto (UAN), no dia 27 de de Julho de 2015, segunda-feira, pelas o9h3om, e discutido com professores e investigadores angolanos.

* Historiador, é Professor da Faculdade de Ciências Sociais e Humanas (FCSH) e Investigador do IPRI - Instituto Português de Relações Internacionais da Universidade Nova de Lisboa (UNL) e Bibliotecário da Casa Cadaval. 
método da descrição densa, a tensão criada entre a familiaridade com o terreno e a preocupação em vigiá-lo criticamente são alguns dos ensinamentos que um historiador pode retirar da leitura de uma série de artigos, capítulos e livros de antropólogos. A este propósito, o inventário de autores, apesar de muito incompleto, terá obrigatoriamente que incluir os trabalhos colectivos de Cristiana Bastos, Miguel Vale de Almeida, João de Pina Cabral, Clara Carvalho, Nuno Domingos e Elsa Peralta, bem como as investigações monográficas de Rui Pereira, Ricardo Roque e Nuno Porto (Pereira 1998: v-LiI; Roque 2001; Porto 2009; Bastos, Almeida, Feldman-Bianco eds., 2004; Cabral, Carvalho eds., 2004; Domingos, Peralta eds., 2013). Para um historiador de ofício, a força dos trabalhos de antropólogos corresponde à sua capacidade, crítica e vigilante, para escapar a simplismos e antinomias, nos quais os historiadores tantas vezes se enredam, ao mostrarem-se incapazes de ultrapassar a reprodução, mais ou menos comemorativa, das próprias ideologias que tomam por objecto de estudo.

A este último respeito, um afunilamento analítico faz-se, hoje, sentir, em seminários, colóquios ou publicações, em correspondência com a seguinte antinomia: de um lado estão os que defendem argumentos de carácter integracionista, procurando a todo o custo prolongar o carácter excepcional de um império colonial que, por ser tão singular, não poderia, nem pode ser considerado como tal, uma vez que se tratou mais de um «mundo que o português criou», luso-tropical, miscigenado, plástico, híbrido e, por isso mesmo, favorável às leituras new age centradas no memorialismo; do outro lado, ficam os que denunciam constantemente as práticas de violência, de exploração, de racismo e de arcaísmo que caracterizaram esse mesmo «mundo», conotado com um império colonial. Que esta antinomia transfere, tantas vezes de forma inconsciente, para dentro dos discursos contemporâneos dos historiadores, duas das posições do campo político definido pelas lutas coloniais do terceiro quartel do século xx, parece uma constatação evidente.

Porém, mais difícil é saber como romper com uma tal antinomia que empobrece a investigação, em lugar de abri-la, obrigando os intervenientes a tomar posição e a auto-satisfazerem-se na rememoração dos termos extremados de um tal oposição. É que a construção de uma ideologia oficial de defesa das colónias e da «presença de Portugal em África», no período posterior à Segunda Guerra, não pode ser reduzida ao luso-tropicalismo de Gilberto 
Freyre, quando este foi considerado quase persona non grata por muitos apoiantes de Salazar. A começar por Ernesto Vilhena que, defendendo uma colonização branca para Angola, contra a mestiçagem, chegou a falar da necessidade de uma «destropicalização do continente africano» (cit. por Carvalho in CRUz e PINTO eds., vol. II, 2005: 770-773, maxime 772). E, claro, com a excepção de Adriano Moreira e dos seus colaboradores, que viram nele um inspirador com capacidade para ajudar a legitimar as políticas coloniais a uma escala internacional. Tão pouco, as críticas à violência e à discriminação podem ser consideradas um monopólio da esquerda e dos que sempre se opuseram a Salazar, uma vez que elas também fizeram parte dos reportórios - plasmados em relatórios e apontamentos - que circulavam nos meios oficiais.

Ora, a profundidade analítica dos já referidos antropólogos corresponde a preocupações internacionais de uma disciplina que, muito mais do que sucede no interior do campo historiográfico, denota elevados padrões de vigilância crítica acerca do trabalho precedente empreendido por etnógrafos e intelectuais. É o que pode ser exemplificado pelas investigações de Rui Pereira e Harry West sobre Jorge Dias (Pereira, «Introdução», in DiAs, op. cit.; West, in HANDLER 2004: 51-90; West, in SANCHES 2007: 141-190). Aliás, estou convencido que a mesma profundidade, modelada pela antropologia, tem atraído membros de outras disciplinas, num jogo de transferências e de insterdisciplinaridade que as novas gerações, mais abertas à inovação, têm sabido compreender. Superficiais, diga-se de passagem, têm sido algumas tentativas para analisar ou simplesmente dar sentido - de um ponto de vista estético, arquitectónico e artístico - a algumas das representações ideológicas do Estado Novo e dos seus projectos coloniais. ${ }^{1}$

Entre as investigações dos referidos antropólogos relativas à análise de ideologias e instituições coloniais, as de Nuno Porto são as que assumiram maior relevância. A crítica que se segue não pode

1 O desconhecimento que muitas dessas análises denotam de projectos, elaborados durante o Estado Novo, nem sempre concretizados, só pode ser ultrapassado com uma atitude mais crítica e vigilante, que não permita apresentar como se se tratasse de uma descoberta, aquilo que surge como produto de uma intenção. É o que acontece nas reflexões para um Palácio do Ultramar na Praça do Império, pelo Subscretário do Fomento Ultramarino entre 1958-1960, Carlos Krus Abecasis, ANTT, AOS/Co/UL-22, n. ${ }^{0}$ 15, fls. 626-633. Para uma abordagem crítica exemplar, ver por todos Nuno Domingos (2015: 235-255). 
esconder a admiração que sinto pelas suas capacidades analíticas e pelo seu modo de colocar questões. Mais. A propósito do Museu do Dundo, no Nordeste de Angola, foi ele quem escreveu as melhores páginas de análise da ideologia colonial do Estado Novo nas décadas de 1940 e de 1950, as quais merecem leitura atenta. No essencial, argumentou, a Companhia dos Diamantes, através dos seus projectos de apoio à investigação e de carácter museológico, construiu a categoria da arte quioca (cokwe); uma tal construção foi um modo de objectivar a dominação colonial, «substantivando processos comparáveis à constituição, nesse mesmo quadro, dos sujeitos coloniais como "trabalhadores nativos"»; ou seja, a ideologia colonial da Diamang procurou identificar, no interior de uma cultura nacional integradora de uma comunidade colonial, uma cultura nativa; nesta,

«o nativo "tribalizado" (ou "retribalizado") é trabalhador, cumpridor das leis, tem os impostos em dia, recolhe à sua sanzala e, nesta ordem de ideias, orgulha-se do seu traje. O seu corpo, em suma, enuncia a civilidade colonial prescrita pelas autoridades, sendo, como o seu oposto destribalizado, identificável a olho nu» (PоRTo 2009: 377, 434).

À luz das pesquisas do mesmo antropólogo, a intenção de fixar uma cultura tribal, em paralelo com a imposição de uma ordem colonial fundada na exploração do trabalhador nativo, poderia ser documentada em relatórios de 1943 e 1951. Através da sua consulta, podia-se demonstrar, por exemplo, o interesse da Companhia dos Diamantes em fazer fotografar os sobas, para criar no museu uma galeria com os seus retratos. Um projecto desta natureza justificavase: pelo apreço que os sobas tinham de ser fotografados; pelo facto de os mesmos serem os representantes dos tipos antropológicos «mais puros das tribos»; e, sobretudo, porque, através desse meio 138 de representação pela imagem, se reconhecia a sua participação nas operações de angariação de mão-de-obra, um dado que também acalentava ideias acerca da sua integração na administração colonial a nível local (Idem, 1999: 58-60, 89, nota 1).

Uma das preocupações de Nuno Porto foi, ainda, a de demonstrar a natureza negocial que rodeou a criação do Museu do Dundo. Para isso, referiu os relatórios anuais da Companhia dos Diamantes, recorreu também ao relato da viagem de Gilberto Freyre, que incluira visita ao mesmo museu, e ainda às sucessivas respostas que 
mereceu da parte de José Osório de Oliveira, nomeadamente no álbum fotográfico intitulado Flagrantes da vida na Lunda (1958). Enfim, Nuno Porto chamou a atenção para a relação existente entre, por um lado, a identificação de uma cultura nativa, tribal (com base no museu, nos trabalhos de investigação de José Redinha e de Marie-Louise Bastin, nas fotografias dos sobas, nas recolhas musicais, no álbum fotográfico e nos catálogos de arte cokwe do referido Osório de Oliveira); e, por outro lado, os interesses pelo trabalho, organizado e disciplinado, da Diamang:

«Na cultura colonial, estabelece-se, deste modo, uma correlação basilar entre a cultura nativa e o poder colonial que a revela, purificando-a de adulterações ocorridas no decurso da implantação colonial e da adopção errática dos signos de uma civilização superior decorrentes. Num extremo dessa correlação está a política nacional, as suas disposições legais e a sua rede administrativa. No outro extremo, o corpo do nativo onde o sucesso ou o falhanço do projecto colonial adquire legibilidade. É a construção de uma corporalidade dócil do sujeito nativo» (Idem, op. cit.: 434).

Arriscaria sumariar o argumento de Nuno Porto do seguinte modo: o Museu do Dundo e o conjunto de iniciativas que suscitou, tanto do ponto de vista da investigação como de outras exposições e representações fotográficas em torno da música e da arte cokwe, fizeram parte integrante da ideologia de estabelecimento de uma ordem colonial da Diamang e do colonialismo português, fundada na exploração do trabalho indígena. Se, no essencial, um tal argumento se afigura mais convincente do que merecedor de críticas, talvez valha a pena revisitar os termos em que o mesmo é enunciado, insistindo nalguns exercícios de contextualização histórica, para assim abrir as portas a interpretações de um outro teor, porventura menos centradas na materialidade dos corpos, mas mais vigilantes das próprias operações de análise histórica ou antropológica.

Assim, um exercício se impõe para compreender melhor o sentido do argumento de Nuno Porto: será que este pretende mesmo dar conta do Museu do Dundo e de todas as suas iniciativas, incluindo as que envolvem representações fotográficas, enquanto produto de uma negociação entre partes envolvidas? Ou reproduz, apenas, um ponto de vista, necessariamente parcial, dessa mesma «negociação»? Parece que vinho novo é servido em odres velhos... Pelo 
menos, é o que parece suceder quanto ao uso dos conceitos de destribalizado e de extermínio, suscitados pelas políticas coloniais e utilizados pelos administradores do Estado colonial; bem como em relação ao estabelecimento de uma correlação entre a exploração colonial e industrial do trabalho indígena e os projectos fotográficos e museológicos de preservação de uma cultura nativa extinta ou em vias de extinção.

$* * * \quad * * *$

No seu relato de viagem pela Lunda, Gilberto Freyre constatou não ter ali encontrado nenhum traço da convivialidade luso-tropical e dos elementos próprios da integração de uma sociedade patriarcal. Em seu lugar o que existia era racismo, ou até apartheid, como o praticavam belgas e sul-africanos - um facto, aliás, que não foi negado pelos defensores da Companhia, quando se insurgiram contra as misturas de pretos com brancos e se pronunciaram contra a miscigenação confundida com a propalada capacidade de adaptação luso-tropical. ${ }^{2}$ A denúncia de Freyre - que não podia ter caído pior nos círculos oficiais do Estado Novo e da Diamang, uma vez que o próprio autor viajara a convite do ministro do Ultramar, Sarmento Rodrigues - surgia acompanhada por duas outras preocupações. Por um lado, a de que a denominada África portuguesa ainda poderia resistir aos riscos do «metropolitanismo», ou seja, de atracção pelas grandes cidades, que inevitavelmente iriam gerar uma massa de proletários desenraizados ou destribalizados, fonte de agitação social e de terrorismo, sendo que o mais importante era que as cidades se conservassem «equilibradas entre o dinamismo urbano e rural» (FREYRE 1953: 420). Por outro lado, Freyre estava bem consciente de que as reivindicações dos africanos, em relação à sua própria situação, oscilavam entre a exigência de condições favoráveis à sua assimilação, incluindo o seu próprio fomento, e a

2 Ernesto Vilhena (1955). A colecção de fotografias que acompanha o Relatório do Conselho de Administração e Parecer do Conselho Fiscal da Companhia dos Diamantes de Angola (s.l., 1954) reitera esta mesma separação racial entre brancos e negros, nomeadamente através da representação de brancos em bailes e equipas de futebol, mau grado também existir uma representação, não encenada, do trabalho de exploração da mina de Caiambo a céu aberto, consultado exemplar em ANTT, AOS/CO/UL - 30, 9. ${ }^{\circ}$ Sub., in fine. 
ideia de «deixar intactos os grupos primitivos para que seu desenvolvimento se processasse normalmente» - sistema considerado menos português e próprio de outros europeus em África (Idem, idem: 37).

Para reconstituir a argumentação de Freyre em relação aos projectos culturais e de pesquisa da Diamang, será talvez necessário começar por recorrer ao estilo das citações longas que Nuno Porto utilizou nos seus livros, a pretexto de dar conta da enorme riqueza de informações contidas nos relatórios anuais da Companhia. Assim, Freyre escreveu em Aventura e rotina:

"A tendência da Companhia dos Diamantes - e das companhias e empresas do seu tipo que operam na África portuguesa do mesmo modo que nas outras Áfricas - talvez seja para reduzir as culturas indígenas a puro material de museu. Os indígenas vivos interessam-nos quase exclusivamente como elementos de trabalho, tanto melhores quanto desenraizados de suas culturas maternas e mecanizados em técnicos, operários e substitutos de animais de carga. A proletarização de tais indivíduos, sua segregação em bairros para "trabalhadores indígenas" dentro de comunidades organizadas em pura função desta ou daquela actividade económica, constitui um dos maiores perigos para a gente africana do ponto de vista social e, ao mesmo tempo, cultural. Está este perigo na destribalização ou desintegração demasiadamente rápida, dos grupos indígenas, sem que se verifique a substituição dos seus valores ancestrais por conjuntos de valores - como os cristãos ou os maometanos - que não se limitando a dar novos trajos aos destribalizados, novos hábitos de alimentação e de recreação às crianças e aos adolescentes, o conhecimento apenas mecânico do Pelo-Sinal e de outros sinais litúrgicos a párvulos e adultos, dê-lhes toda uma nova base de desenvolvimento pessoal e social. As consequências, desfavoráveis ao indígena, da desintegração da sua cultura são quase inevitáveis, sob o impacto do industrialismo capitalista» (FREYRE, op. cit.: 432). ${ }^{3}$

3 Sublinhado de destribalização nosso. Também citado por Ernesto Vilhena (?), op. cit., pp. 39-40. Sobre a noção de destribalização, cf. George W. Stocking, Jr. (1991: 9-74, maxime 53, 55-58, 65); Diogo Ramada Curto e Bernardo Pinto da Cruz (2015: 113-172). 
A correlação entre a exploração de novas formas de trabalho, pelos modernos processos de desenvolvimento do capitalismo implicando processos de destribalização e a criação de bairros proletários segregados - e a redução das «culturas indígenas a puro material de museu» é, pois, bem clara na visão de Freyre. A denúncia de Freyre, em relação aos métodos de exploração do trabalho indígena, não era inédita. Nos próprios meios oficiais, do governo e da administração de Angola, havia antecedentes do mesmo tipo de denúncias, a começar pelos relatórios de Henrique Galvão, que relacionavam a exploração do trabalho compelido ou por contrato com o processo de intensificação do capitalismo. Por exemplo, em Março de 1951, o Governador Geral de Angola José Agapito da Silva Carvalho escreveu uma longa exposição ao Ministro das Colónias, reagindo contra a Administração da Diamang que não aceitava reduzir de 18 para 12 meses o tempo dos contratos. Nessa mesma exposição de 28 páginas dactilografadas, são várias as referências ao trabalho compelido e às condições de extrema dureza de exploração dos trabalhadores indígenas, a contrastar com o que sucedia no Congo Belga. Nela, o seu autor recorreu a um parecer do mesmo teor, escrito pelo Major Bento Roma, na sua qualidade de Governador da Lunda (1920-1923), no qual fora posto a nu o modo como os trabalhadores indígenas eram tratados, em jornadas contínuas de trabalho e sem comida:

«Acrescentavam que o indígena é como uma máquina a vapor que, para trabalhar devidamente, precisa é de se pôr primeiro em pressão; que com o preto sucede o mesmo e que, havendo no meio do trabalho um descanso, a pressão perde-se e novo tempo será depois preciso para novamente fazer vapor. Poderão ter muita razão mas acho preferível fazer vapor indígena duas vezes por dia durante muitos anos, embora a menor pressão, do que fazê-lo uma só vez por dia durante poucos, ainda que com pressão elevada». ${ }^{4}$

O relatório de Agapito da Silva Carvalho, nas suas denúncias, não andaria longe de algumas das ideias de Henrique Galvão que, desde finais da década de 1930, tinha manifestado a mesma apreensão relativamente ao modo como os trabalhadores indígenas eram, na

4 ANTT, AOS/Co/Ul - 61, Pt. 3, fl. 82. 
prática, escravizados. Porém, importa separar as esferas em que tais denúncias circularam. Em gabinetes e em círculos administrativos ou burocráticos a voz dissonante, crítica, não equivalia necessariamente a uma forma de oposição ou de resistência. E a prova desta separação encontra-se no facto de que, quando Galvão e Carlos Selvagem se pronunciaram acerca da Diamang, precisamente em 1952, referem-se-lhe como a primeira das «grandes empresas económicas» que contribuía para «a colonização de Angola», ou seja, "a mais notável empresa privada de Portugal e a que mais extensa e superiormente tem afirmado sentido e capacidade colonizadoras», podendo ser considerada muito simplesmente «uma espécie de nona Província à margem do conjunto político» (GALvão e SELVAGEM, III, 1952: 354). ${ }^{5}$ Essa diferença entre aquilo que se dizia ou era possível dizer, criticamente, em circuitos restritos ou oficiais e o que, de facto, eram as tomadas de posição públicas, muitas vezes envolvendo as mesmas pessoas, parece ter sido uma característica imposta pelo Estado Novo. Não será, por isso, de estranhar que outros intelectuais durante a década de 1960 continuem a falar e a escrever de modo diferente, consoante os circuitos restritos - onde podiam criticar as políticas seguidas e exprimir a sua dissensão ou a esfera controlada de uma opinião pública, muito mais modelada pelos mecanismos da censura e da propaganda.

Em relação às opiniões anteriores, Gilberto Freyre foi mais longe na sua denúncia, não só porque a trouxe para o espaço público internacional, mas também por considerar que o extermínio da cultura indígena era acompanhado de uma espécie de mascarada, representada simbolicamente pelo museu e pela representação de um "pobre soba carnavalesco», quando o que estava em causa era que as grandes empresas capitalistas, como a Diamang, com o seu racismo, exploravam e humilhavam o trabalhador nativo, procedendo à sua inevitável destribalização:

«Deixo-me fotografar, no próprio Museu, ao lado de um velho soba, vestido como nos seus velhos dias de príncipe e que a Companhia conserva para dar pitoresco às ruas do Dundo. Um pobre soba carnavalesco. Sua sobrevivência, como figura já quase de museu, é

5 Sobre memórias recentes da escravatura na Lunda, pela Diamang, antes de 1960, cf. José Luís Pinto de Sá (2006: 30-32). 
simbólica de toda uma política de exterminação violenta e rápida, das culturas indígenas, a que se sentem obrigadas as grandes empresas capitalistas na África, mais necessitadas dos outrora chamados "fôlegos vivos". Necessidade semelhante às das grandes plantações de tipo patriarcal, à sombra das quais formou-se e desenvolveu-se o Brasil: também elas fundaram-se e desenvolveram-se com negros arrancados a tribos africanas. Mas incorporados a um sistema -o patriarcal, o familial, escravocrata - que era cristão não apenas de boca mas sociologicamente válido no sentido de dar novo status ao preto cristianizado [...]. É o que não acontece dentro das grandes empresas capitalistas que hoje se instalam na África e utilizam-se de africanos arrancados às suas tribos sem lhes darem oportunidade de participação em novos sistemas de convivência e de cultura. São eles mantidos num ambiente socialmente artificial - e não só artificial: humilhante - do qual só pode resultar a sua degradação [...]. O estado de escravo no sistema patriarcal luso-brasileiro nada tinha de fixo: era transitório, plástico. $O$ indivíduo poderia superá-lo. $O$ estado de "trabalhador nativo" do africano destribalizado, dentro das grandes empresas capitalistas instaladas na África, é uma situação de condenado sociologicamente à morte. Baseia-se na concepção de ser ele inferior ao branco, não transitoriamente - como cativo de guerra ou devido a outro acidente - mas como raça. Biologicamente. Fatalmente» (FREYRE op. cit.: 433-434).

Para se reconstituir a que «negociação» pertencem as interpretações de Freyre, será necessário tomar em conta a visão dos que o precederam, na denúncia das formas de exploração do trabalho empreendidas pela Diamang (tal como pode ser exemplificado, em 1951, pelo relatório do próprio Governador de Angola, que apoiara em 1949 a candidatura à Presidência de Norton de Matos); bem como dos que se lhe opuseram, de modo quase imediato, contribuindo para a criação de um discurso oficial da Companhia, que tentará obter o apoio dos agentes e representantes do Estado colonial (ultrapassando as diferenças de entendimento, como acontecera, em 1951, no referido parecer de José Agapito da Silva Carvalho). Assim, na oposição à visão dicotómica de Freyre - que distinguia entre as tribos, com as suas culturas nativas, e os trabalhadores «destribalizados», explorados pelo Companhia capitalista -, encontravam-se ideias menos contrastadas, que eram consideradas mais realistas, logo, mais conformes com o que sucedia na prática: 
«Há ainda a considerar, no nosso caso especial, que um grande número de trabalhadores serve a Companhia por contrato de alguns meses findo o qual regressam às suas terras, e nenhuma vantagem haveria para eles, nem para nós, em que se iniciasse, pelo confronto entre os que teriam deixado e os que voltavam a encontrar na terra de origem, aquela "destribalização" (perdoe-se o galicismo, hoje usual), tão justamente condenada em relação ao grosso das populações indígenas que por muito tempo ainda terão de continuar subordinadas, nos seus usos e costumes, às condições originais dos grupos étnicos a que pertencem» (VILHENA op. cit.: 30). ${ }^{6}$

Quem defendia tais ideias - subscritas em nome do administrador da Diamang, Comandante Ernesto Vilhena, que então contava quase 80 anos - também considerava a necessidade de exercer sobre essas mesmas culturas uma qualquer missão civilizadora, «pela acção do branco» (Idem, idem: 41). ${ }^{7}$ Isto porque, através do exame de tais culturas, como era praticado pelos «cientistas de Dakar» em relação à «Afrique Noire», não se podia concluir que a partir delas fosse possível alcançar o nível de «verdadeiras civilizações» (Ibidem).

«Basta reflectir em que tão longe quanto se pode remontar na história dos negros a que nos estamos referindo, se constata tratarse de culturas estagnadas, sem resistência a influências degradantes, e que só pela acção do branco têm podido conservar-se e, por vezes, aperfeiçoar-se. E não nos falem nos "duques" e "marqueses" da chamada "corte do Rei do Congo", que nunca chegaram a existir com as categorias e a pompa que lhes quiseram dar, nem nos venham com o argumento de que o Zimbaoé e outras semelhantes edificações da Rodésia são obra de antigos bantu, pois continua a ser incontestável que elas devem a sua erecção a povos invasores de origem semita préislâmica, ou mesmo "galla", e nunca aos antepassados dos machonas ou matebeles de hoje. E é necessário não esquecer que o que presentemente encontramos nas "culturas" indígenas aparece já expurgado, dos seus caracteres menos aceitáveis, como são os sacrificios humanos,

6 Sublinhado de «destribalização» nosso.

7 «Muitos pensarão que um programa tão radical de povoamento e de genuína acção do português de raça branca em Angola, como o que sumariamente acabo de enunciar, é de impossível realização. Não o é» (Idem, idem: 57). 
a antropofagia, o poder absoluto do feiticeiro, as situações de escravidão, elas próprias resultantes, em grande parte, de um estado endémico de contínuas guerras e depredações, a poligamia, em parte, com a consequente servidão da mulher, e outros ainda; mas, mesmo depuradas, essas culturas revelam-se pobres de elementos aproveitáveis, salvo no relativo a certas artes, como a música, a pintura rupestre, a fundição em bronze (em área muito restrita), a escultura, designadamente em madeira, que neste momento é alvo de justificada curiosidade e interesse mas que, nem por isso deixa de se revestir de uma feição caricatural e infantil que logo revela o seu primitivismo, o qual poderia talvez evolucionar no sentido das modernas produções chamadas “abstractas”, mas sem que, a meu ver, dessa eventual evolução viesse a resultar perfeição ou enriquecimento dos valores essenciais das artes referidas» (Idem, idem: 41-42).

Figura 1. «Simulacro do antigo costume de execução do prisioneiro ("mussuico") para termo de hostilidades» (Cacongos do Nordeste)

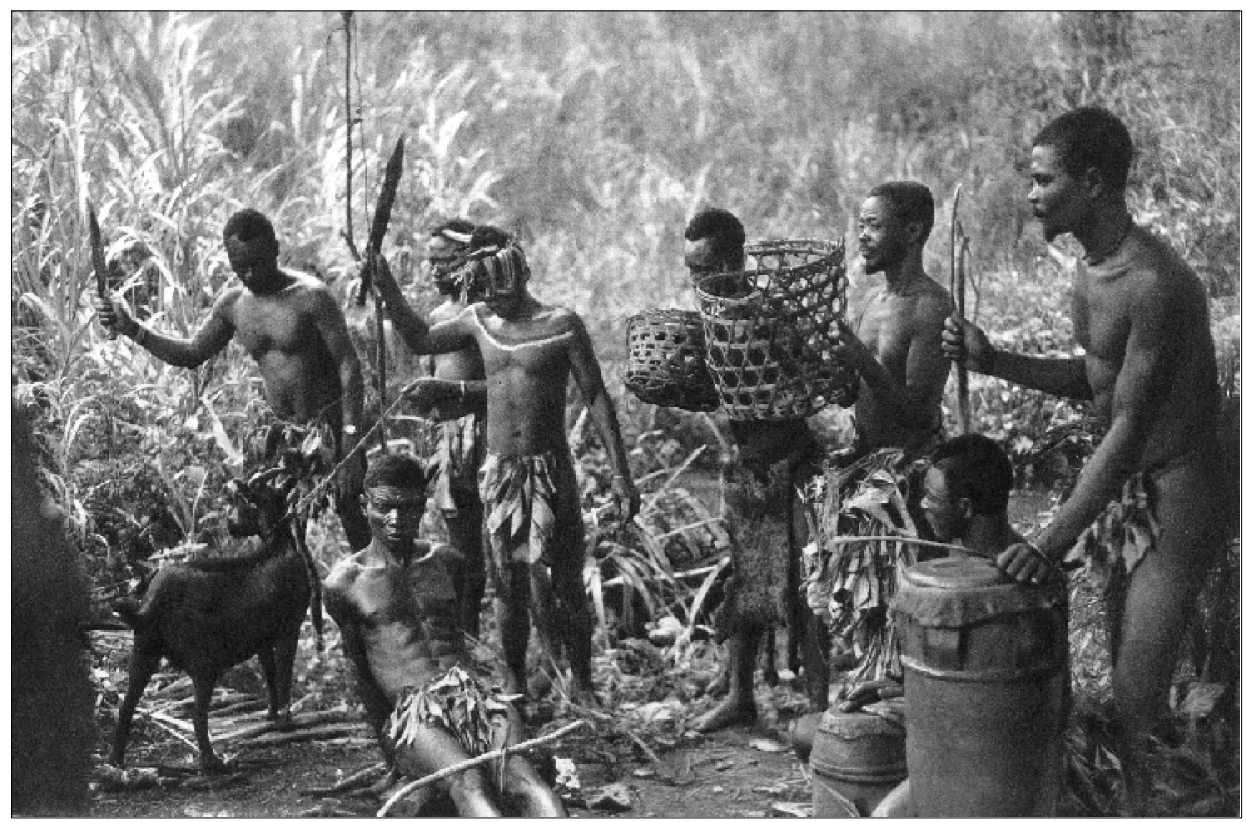

Fonte: José Osório de Oliveira, Flagrantes da vida na Lunda (Lisboa, Companhia de Diamantes de Angola, 1958, «Publicações Culturais», n. ${ }^{\circ}$ 37), p. 110. 


\section{Figura 2. «Chegado para a Festa Grande no Dundo: um soba com as suas mulheres»}

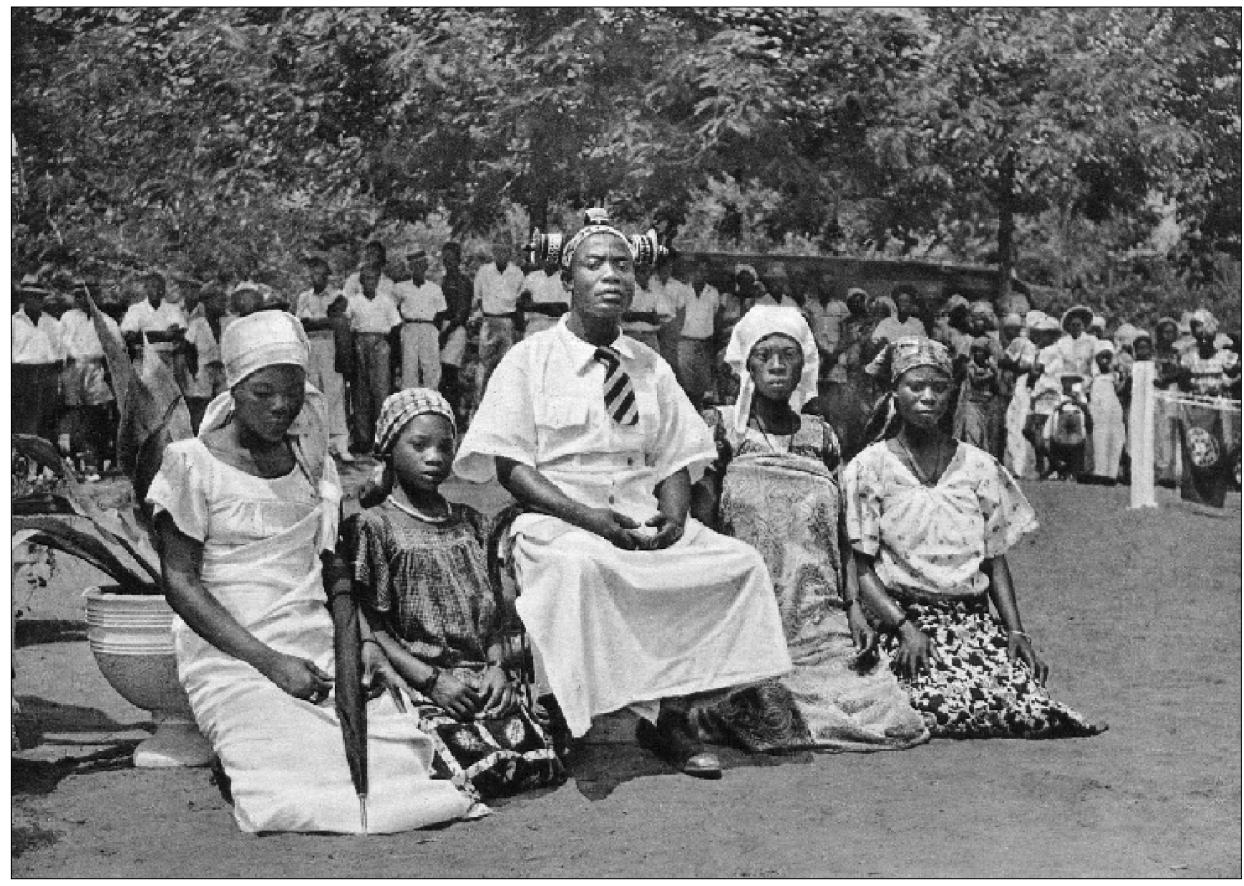

Fonte: José Osório de Oliveira, Flagrantes da vida na Lunda (Lisboa, Companhia de Diamantes de Angola, 1958, «Publicações Culturais», n. ${ }^{\circ}$ 37), p. 135.

Assim, ambos os lados pareciam considerar a destribalização como um processo inevitável. Embora os defensores da visão oficial da Companhia, notassem que ela tinha de ser progressiva. Por exemplo, um indígena tratado por um verdadeiro cirurgião e curado já não poderia aceitar os remédios do curandeiro nativo que conduziram à morte os seus conterrâneos (Idem, idem: 45).

São sempre grandes os riscos de reproduzir para efeitos analíticos, investindo-os de um valor de operatórias, conceitos utilizados por administradores, políticos e cientistas sociais ao serviço de poderes coloniais. E se Nuno Porto reproduziu, parcialmente e de forma involuntária, os argumentos de Gilberto Freyre quanto ao Museu do Dundo, fundado em noções acerca da destribalização tão 
Figura 3. «Na sala de tratamentos do Hospital de Andrada»

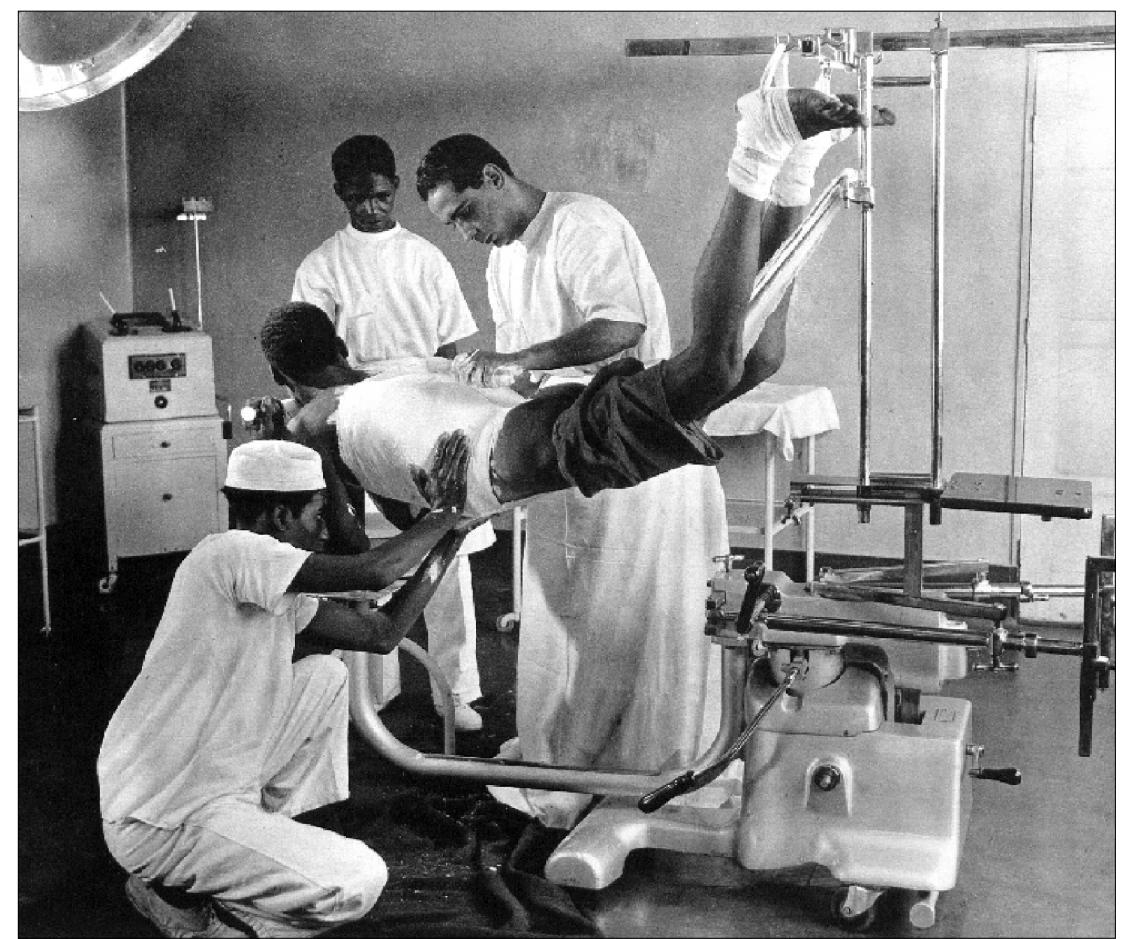

Fonte: José Osório de Oliveira, Flagrantes da vida na Lunda (Lisboa, Companhia de Diamantes de Angola, 1958, «Publicações Culturais», n. ${ }^{\circ}$ 37), p. 125.

em voga nos meios administrativos e políticos do Estado colonial, deixou de lado uma certa nostalgia pelos modelos de integração patriarcal, tão caros a este último. A resposta directa às denúncias de Gilberto Freyre em relação à Companhia dos Diamantes, que incluíam referências a uma atmosfera de suspeição, de controlo ou mesmo de terror instalado pelos seus dirigentes, competiu ao já referido José Osório de Oliveira. Nuno Porto apresentou-o como o introdutor da obra de Freyre ao público português e que tal teria sucedido, em 1938, nas páginas de O Mundo Português; considerou também que, depois de visitar a Lunda em 1953, Osório preparou uma série de respostas começadas a publicar em 1954; para além da responsabilidade que teve na organização de várias exposições europeias de arte chokwe, sendo que a mais importante dessas respostas, veio à luz em 1958, tendo sido constituída pelo já referido álbum fotográfico; sobre este último, Nuno Porto concluiu que, para Osório, 
«a participação da Companhia no extermínio colonial das condições sociais de produção dessa arte é liminarmente ignorada em favor do reconhecimento de uma missão de salvação cultural e científica. Mais do que isso, o facto de o extermínio dessas condições constituir um ponto de partida necessário ao estabelecimento da categoria de arte (antigo, pré-colonial, for de produção, raro) não chega sequer a ser colocada» (РоRTо op. cit.: 376, 537, 539, 541-555, 571-576, maxime $576){ }^{8}$

Mas, afinal, quem era José Osório de Oliveira? Para Nuno Porto, era o introdutor da obra de Freyre, escrevia a soldo da Diamang, encantara-se com o Museu do Dundo e com a arte chokwe, mas era destituído da capacidade para colocar questões acerca do extermínio das condições sociais de produção da arte e da cultura que estudava, fotografava e exibia internacionalmente. Ora, tanto estas pinceladas biográficas podem ser consideradas redutoras da vida e obra de José Osório, como se afigura injusta a avaliação das suas capacidades, enquanto intelectual profundamente comprometido com o Estado Novo e com as suas políticas coloniais. Funcionário colonial e da Agência Geral das Colónias, Osório vivera no Brasil, onde seu pai, Paulino de Oliveira, republicano exilado no Brasil no final da Monarquia, serviu como cônsul de Portugal em São Paulo (1911-1914). Depois, ocupou diversos lugares e postos coloniais, em Moçambique e Cabo Verde (FERrEIRA 1986: XXIII-XXv). As ligações de sua mãe, Ana de Castro Osório, aos meios republicanos talvez expliquem por que razão manteve ligações com os círculos da oposição ao Estado Novo, nomeadamente com os seareiros e, entre eles, sobretudo com António Sérgio, até pelo menos ao início da década de 1930.9 Porém, as suas crescentes afinidades com o Estado Novo (talvez por influência e devido à viragem da sua própria mãe a partir dos anos 1920), com a sua política cultural, sobretudo nos domínios coloniais, são inequívocas. Bem representadas ficam através do seu envolvimento em revistas tais como: a Descobrimento (1931-1932), dirigida por seu irmão, João de Castro Osório, mas de que ele era editor; o Mundo português (1934-1947); e, sobretudo, a Atlântico (1942-1950) (SARAIVA 1986: 96).

8 Sublinhado de «extermínio» nosso.

9 Biblioteca Nacional de Portugal, Espólios, N 24 - «Espólio de José Osório de Oliveira», n. ${ }^{\circ} 81$ [Carta de Joaquim de Carvalho, Coimbra 26-2-1930: «satisfação 
Em 1937, Carlos Malheiro Dias revelou quantas esperanças depositava em Osório de Oliveira - ao lado de Mário de Albuquerque - para dar corpo à verdadeira «Revolução Nacional» que estava por cumprir e que se deveria aproximar dos rasgos de Hitler e Mussolini, afastando-se das vistas estreitas de Salazar, preocupado ad nauseam com a economia. ${ }^{\mathbf{1 0}}$ Tais esperanças resultariam no projecto de uma revolução que se submetesse ao «ideal nacional de educação artística». Mas as relações entre Malheiro Dias e Osório remontavam, pelo menos, a 1924 e redundaram na carta-prefácio que aquele escreveu para um opúsculo deste último intitulado Literatura brasileira (Porto). ${ }^{\mathbf{1 1}}$ Depois de ter participado, na década de 1930, na pro-

intellectual pela serena limpidês do seu artigo da Seara»]; n. ${ }^{\circ} 8$ [Carta de Joaquim de Carvalho, Coimbra, 29-4-1930: «Não publicarei na Seara a alocução [...] porque a inserção na Seara concorreria para avolumar a especulação política que se fez e me coagiu a adiar a ida para França»]; n. ${ }^{\circ} 89$ [Carta de Joaquim de Carvalho, Coimbra 10-5-1931: «Há um mês que não tenho sossego [...] a incerteza do meu dia de amanhã. Agora começo a tranquilizar-me, e a prova é que já hoje trabalhei. Se lhe disser que cheguei a escrever para o Rio para ganhar a minha vida, ter-lhe-ei dado uma mostra das inquietudes que são as inquietudes de um pai de 8 filhos, que não tem outros rendimentos que os do seu trabalho [...]. PS: Peço-lhe que me diga o vaticínio que por aí fazem, vamos, após estes dias de hesitação, para o miguelismo mais arrogante ainda? Para próxima epístola, longa, o juízo sobre Descobrimento e outras coisas»]; n. ${ }^{\circ} 100$ (Carta de Joaquim de Carvalho, Coimbra, 1-11-1932, critica um livro de Madariaga, com quem falara em Santiago de Compostela: «A Espanha é uma nação saudosa da antiga posição europeia. O seu ideal é um ideal de potência europeia, como a França. O nosso, pelo contrário, não é europeu. A Europa interessa-nos na medida em que favorece ou prejudica o nosso ideal ultramarino, de sorte que mantemos no fundo a persistência do ideal quinhentista. E mais disse, que, por isto, o centro da nossa politica internacional nunca pode basear-se num país do continente - razão primitiva da aliança inglesa na idade-média, a qual é ainda actual. E calaram-se porque o argumento não é especioso, mas objectivo»]; n. ${ }^{\circ} 479$ [Carta de António Sérgio, Paris, 1-2-1932, onde refere que revia provas do Leibniz «que fiz para a Imprensa da Universidade, a pedido do nosso admirável Joaquim de Carvalho»; indica que tratava de tudo que dizia respeito ao Proença e aos problemas dos emigrados necessitados em França e na Bélgica].

10 Biblioteca Nacional de Portugal, Espólios, N $24-$ «Espólio de José Osório de Oliveira», n. ${ }^{0} 190$ [Carta de Carlos Malheiro Dias, 13-12-1937, onde se refere que, na lamentável criação cultural e artística do Estado Novo, «não há uma nota inédita, uma vibração criadora», tudo se reduzia, em parte, a exibições de indumentária regionalista, «não passamos de cenografia [...]. Somos pobres e não podemos imaginar essa revolução nacional à maneira de Hitler e Mussolini. Economias! Economias! Mas podíamos submetê-la a um ideal nacional de educação artística»].

11 Biblioteca Nacional de Portugal, Espólios, N 24 - «Espólio de José Osório de Oliveira», n. ${ }^{\circ} 186$ [Carta de Carlos Malheiro Dias, Porto, 18-12-1924: «Quando 
moção da literatura, da cultura e do crioulo cabo verdiano, Osório multiplicou, a partir de 1940, as suas publicações acerca das literaturas africanas e da cultura brasileira. Na sua antologia de ensaístas brasileiros, incluiu Freyre (que conhecia pessoalmente, desde 1930, e com quem trocava correspondência desde 1931). ${ }^{12}$ O mesmo sucedeu a um texto de Sérgio Buarque de Holanda, que Osório conhecera em $1923 .{ }^{13} \mathrm{Na}$ mesma década de 1940, a sua rede de contactos nacionais e internacionais foi explorada na Atlântico, revista que foi lançada e dirigida por António Ferro, mas da qual Osório foi secretário do primeiro ao último número e, muito provavelmente, o

ia dispor-me a escreve-lo, surge O Desejado de Ant. Sérgio, que me impoz a necessidade de uma resposta imediata em prefácio também a que dei o titulo de O Piedoso e o Desejado. Projectara dar um grande desenvolvimento ao prefácio, destinado ao seu livro e, na impossibilidade de repetir-me, encontro-me forçado a deslocar grande parte da matéria para a minha replica a A.S. Ofereço-lhe, pois, meu amigo, à sua escolha, ou um menor prefacio para já, ou mais extenso para depois da publicação do meu livro. O momento é decisivo. Trata-se de saber se o nacionalismo-espiritualista dos que querem um Portugal português governado pela qualidade (e não pela quantidade) caminha com seus cavaleiros e capitães para uma Aljubarrota ou para um Alcácer-Quibir. Temos que estabelecer uma doutrina, firmar um progresso. Os novos dirão se querem firmar apenas com a Razão, ou se lhe preferem a Fé associada à Razão. Patriotismo é idealismo. [...] Para sahirmos do pântano em que jazemos precisamos de asas. A.S. convida a Mocidade a adorar a Razão. O templo que lhe elevaram em Paris não salvou a França. Eu quero, sim a Razão, mas ao serviço do ideal. É isto ser romântico?»].

12 Biblioteca Nacional de Portugal, Espólios, N 24 - «Espólio de José Osório de Oliveira», n. ${ }^{0} 239$ [Carta de Gilberto Freyre, Stanford, 9-4-1931: "Me mande o $n{ }^{o} 1$ da Descobrimento que eu quero ver logo o typo da revista [...]. O muito trabalho que tenho aqui com os meus cursos - um de conferências, outro de seminar (systema allemão americanisado). Muito lhe agradeço o livro do Sérgio, que me tem sido de muito valor com relação à história de Portugal e que recomendarei»]; n. ${ }^{\circ} 240$ [Carta de Gilberto Freyre, Recife, 3-1-1937, onde escreve que com a colaboração do editor José Olympio e a direcção de Osório de Oliveira pretendia alargar o movimento literário da nova geração a África e à Índia portuguesas]; n. ${ }^{\circ} 241$ [Carta de Gilberto Freyre, Recife (?),18-5-1939, avisa Osório de Oliveira que este ano dirigirá cursos em Michigan: «Sei que V. não morre de amores pelos Estados Unidos mas a verdade é que suas universidades são hoje a melhor esperança para uma vida intellectual não só livre de "totalitarismos" absorventes como para uma renovação, de tal modo se vem enriquecendo de alguns dos melhores elementos de outros paizes, não só europeus como da Ásia e da América»].

13 Biblioteca Nacional de Portugal, Espólios, N 24 - «Espólio de José Osório de Oliveira», n. ${ }^{\circ} 281$ [Carta de Sérgio Buarque, Rio, 4-7-1943: «Ha muito que deveria ter acusado os dois livros que V. gentilmente me mandou e que me trouxeram boas recordações daquelas noites de 1923. Quando mais tarde (1933) V. andou aqui pelo Rio pouco nos encontrámos»]. 
principal mentor. Desde 1952, aquele que podia ser considerado um intelectual orgânico do Estado Novo passou a trabalhar em missões patrocinadas pela Diamang (Oliveira 1952; idem 1954; idem 1956: 1-11; idem, III, 1956: 253-256; idem, idem: 439-444; idem 1958). Pelo teor da argumentação utilizada, muito mais dura do que nos seus livros, pode colocar-se como hipótese que a já citada resposta, subscrita pelo Comandante Ernesto Vilhena, administrador delegado da Companhia dos Diamantes e grande bibliófilo, foi por ele preparada - num jogo literário próximo da heteronímia, tão ao seu gosto (LEAL vol. I, 1957: 115). ${ }^{14}$ O mesmo se diga do guião intitulado Argumento do filme intitulado «O Romance do Luachimo-Lunda, terra de diamantes», onde também se sente a mão de José Osório, apesar de este nunca ser designado como autor. ${ }^{15}$

Nem por sombras se pretende traçar, aqui, a biografia de Osório de Oliveira. Tão pouco se tenta fazer o elogio das suas qualidades, enquanto intelectual totalmente comprometido com o Estado Novo, para poder resgatar a sua memória do estatuto de menoridade que Nuno Porto lhe atribuiu. O único objectivo é pôr em causa a operação de um investigador que se julga autorizado a dar sentido a uma acção, neste caso de extermínio de uma cultura, repetindo os

14 Ao acusar Ernesto Vilhena, defendido por Azeredo Perdigão, de auferir remunerações fabulosas da Companhia dos Diamantes, o autor atribuiu ao primeiro os dotes intelectuais de um «afamado Demóstenes, "doublé" de P. Agostinho de Macedo, da Rua dos Fanqueiros, artéria citadina que corre paralelamente à Rua dos Sapateiros»; e reservou para o segundo o qualicativo de «socialista de pura água». Cunha Leal (1959, II: 29) voltou a referir-se a Ernesto Vilhena, como «o Demóstenes da Companhia de Diamantes de Angola».

15 Argumento do filme intitulado "O Romance do Luachimo-Lunda, terra de diamantes» (Propriedade da Companhia de Diamantes de Angola, S.A.R.L., com sede em Lisboa, na rua dos Fanqueiros, $n .^{o} 12-2 .^{\circ}$ ), exemplar dactilogrado assinado pelo administrador delegado da Companhia dos Diamantes, Comandante Ernesto Vilhena, Lisboa, 5 de Março de 1963 (Biblioteca Nacional de Portugal, cota SA 31103v). As considerações feitas, neste mesmo argumento para um filme, acerca dos jogos, práticas atléticas e distribuição das medalhas por trabalhadores, enquadrados pelos sobas, estão próximas do que se refere em Flagrantes da Vida na Lunda... (op. cit.: 12-15, maxime 13-15): «O cenário é impressionante. No território de jogos, cerca de oito centenas de trabalhadores que representam os diversos serviços da Companhia, são portadores de dísticos e de bandeiras nacionais. Ladeiam-nos trabalhadores a homenagear e sobas no total aproximado de 500 pessoas». O interesse de José Osório pela cinematografia pode ser documentado, por exemplo, na sua crítica ao «Vendaval Maravilhoso» de Leitão de Barros, Atlântico - Revista luso-brasileira, $3 .^{a}$ série, n. ${ }^{\circ} 3$ (1950), pp. 110-112. 
mesmos termos da referida «política de exterminação» de Gilberto Freyre e considerando que quem extermina nem sequer está disso consciente. Sem preocupações de alcançar a exaustividade, por mais extravagantes que possam parecer, são dignas de nota duas outras operações levadas a cabo por José Osório, que aqui tentarei reconstruir de forma breve, uma vez que elas indiciam a sua vigilante consciência crítica em relação às condições de produção de sentidos culturais, em contextos bem determinados. Constatação que, só por si, põe em causa a pretensão do antropólogo dobrado de historiador de devolver consciência a quem surge, a seus olhos, destituído dela. ${ }^{\mathbf{1 6}}$

A primeira operação está situada quase nos limites da própria literatura, embora se lhe possa atribuir o estatuto de peça única, de uma rara beleza. Trata-se de um exemplo extremo ou, pelo menos, perturbante. Em 1946, José Osório publicou duas cartas que lhe foram dirigidas por Mário de Andrade. Duas cartas onde o autor de Macunaíma, assumiu a sua homossexualidade, revelando a sua «feminilidade» e celebrando, no «amor do todo», a sensualidade do seu corpo e dos índios da Amazónia. Andrade justificava-se com a sobreposição de identidades que em si coexistam, uma espécie de desdobramento do seu próprio eu ou de uma heteronímia que os portugueses associam logo a Fernando Pessoa, mas cujas origens bebem em muitas outras fontes. As cartas, confessionais, são datadas de 1934 e 1937. Na última carta, Andrade escreveu:

«Sua carta admirável merece vários reparos. Pelo menos é preciso uma mise-au-point de certas coisas. Você acha possível um indivíduo distinguir em si vários seres, até com bastante nitidez de limites entre um e outro, e deixá-los cada qual ser e agir diferentemente?... Creio que você dificilmente aceitará isso, não porque lhe falte inteligência, mas porque você é europeu, quero dizer tem uma inteligência lógica. Meu Deus, como os europeus são pobremente, restritamente lógicos! Ao que autorizo você a exclamar "Meu Deus como os americanos são primária, descivilizadamente contraditórios!”》(OLIveIRA ed., 1946: 1-7 maxime 4).

16 De notar que algumas das mais profundas reflexões sobre os usos da fotografia e os modos de exposição dos africanos às mesmas, em conjunto com mais do que óbvias visões racistas em relação aos regimes de trabalho indígena, encontram-se no relato de viagem de Geoffrey Dutton (1956: 87-91, 104-105, 120). 
E é nessa mesma carta que Andrade mostra ao amigo como a sua escrita tal como a sua convivência, assumindo um carácter deletério, faziam subir nele «a sombra dum suicídio de moço». Os nexos causais e as motivações são, a este respeito, difíceis de traçar, mas de novo surgem ligados à própria confissão de uma discreta homossexualidade do autor da carta: «Não sei, meu amadíssimo Osório, si você continuará me aceitando assim tão negro, tão moralmente podre. Salva-se apenas que esta podridão eu guardo para mim» (Idem, idem: 5 ). ${ }^{17}$

As duas cartas de Mário de Andrade, com as revelações da homossexualidade do seu autor e respectivas justificações, fundadas no elogio da contradição da mesma personalidade, teriam com certeza menos importância se tivessem sido mantidas numa esfera privada. Mas Osório de Oliveira publicou-as numa revista do Secretariado Nacional de Propaganda (SNP) dirigida por António Ferro e da qual ele próprio era o secretário da redacção. Porquê? Para se distinguir através de uma transgressão, desviando-se claramente da cultura homofóbica do Estado Novo? Para se associar, de qualquer maneira, a um dos maiores nomes das letras brasileiras, demonstrando que com ele privara e nele encontrara inspiração para conjugar criação literária com ensaísmo, em particular de sentido etnográfico? Por entender que, mesmo no centro da cultura oficial fascista, existia uma margem clara para a dissensão, sobretudo quando esta surgia associada à produção de formas simbólicas ou literárias modernistas? Talvez por todas estas razões. Mesmo que seja difícil determinar o significado mais pertinente de um tal acto, dado o carácter extravagante que a publicação das duas cartas assume, será muito difícil considerar que ela resulta de uma qualquer falta de consciência, de uma espécie de absent mind. De qualquer modo, será sempre de considerar que havia em José Osório um fascínio por Mário de Andrade, figura que ele terá porventura procurado mimetizar, à sua própria escala. Sabia, por experiência de contacto directo, e, porventura por se rever na imagem polifecatada de Mário de Andrade que, como argumentou Sergio Miceli:

17 Sobre a correspondência de Mário de Andrade, cf. Marcos António de Moraes (2003: 33-47). 
«No intuito de compensar a falta de património, de títulos escolares prestigiosos, e mesmo de um capital de relações sociais, suas investidas cobriram quase todos os domínios de conhecimento humanístico da época - da literatura às belas artes e à música, da etnografia ao folclore e à história. Em lugar do polígrafo típico da geração precedente, prensado entre as encomendas da imprensa e os géneros tradicionais da poesia e do ensaio impressionista, Mário se firmou como intelectual polivalente que destoava por completo dos companheiros de geração. Assumiu os riscos de avis rara e logrou-se impor como escritor inventivo e líder por convicção» (Miceli 2012: 108).

A segunda operação, que aqui expomos, encontra-se num dos últimos textos resultantes do envolvimento de Osório de Oliveira com a escultura chokwe. Trata-se de um conto, intitulado "A máscara», que foi publicado inicialmente num jornal de província e, logo de seguida, num livro com o título ambíguo de Tempo de exílio (1961). ${ }^{18}$ Como poderia um dos intelectuais mais influentes do Estado Novo, com acesso privilegiado durante três décadas aos mais diversos meios de comunicação, falar de exílio a não ser por artifício literário? A mesma questão é igualmente suscitada pelos títulos de outras das suas obras publicadas pela mesma altura: Sonho inútil (1957), Fogueiras no deserto (1959) e Ilha do desencanto (1963). O conto descreve a biblioteca do próprio narrador, que simboliza a cultura europeia, «greco-romana, cristã ou racionalista», com os seus livros clássicos e retratos de escritores, tais como gravuras de Goethe ou Schiller. Vénus não faltava, na reprodução de um pintor italiano do Renascimento. Em contraste, uma máscara africana estava pendurada numa das paredes. Qual o significado da máscara «de bailarino das danças rituais africanas»? É a questão que o conto enuncia, como se se tratasse de um enigma. E, ao longo da narrativa, insinuam-se algumas respostas. A máscara era recordação de um tempo passado em África, uma experiência de vida que trazia um efeito do real, ao intelectual que, agora, vivia rodeado dos seus livros. A máscara servia, também, para evocar uma cultura, mais sensorial, associada a uma qualquer aventura amorosa, base-

18 José Osório de Oliveira, «A máscara africana», A Ilha - Semanário cultural e informativo, 3-12-1960 [a referência a esta publicação original foi-me generosamente facultada por Vasco Rosa]; conto reeditado em Tempo de exílio (1961: 65-68). 
ada na experiência sexual com uma jovem africana, que curiosamente falava francês, sendo capaz de libertar sentidos à flor da pele e pulsões selvagens. Mas a máscara, que na imaginação do narrador se metamorfoseia ao longo do conto, representava também, na sua fealdade, no seu «génio maléfico», aquilo que era denominado, com todas as letras, de «ódio racial» dos africanos em relação aos europeus. A ter em conta que a publicação em livro do mesmo conto corresponde ao início da guerra em Angola, em 1961, a máscara acabava por simbolizar a resistência africana à dominação colonial dos europeus. Ou seja, sob a forma imaginada de um conto, José Osório espreitou o ponto de vista dos inimigos, movidos pelo já referido ódio racial. Longe, mesmo muito longe, parecia estar do significado de «harmonia multirracial» atribuído ao álbum que publicara, intitulado Flagrantes da vida na Lunda. ${ }^{19}$

$* * * \quad * * *$

A crítica aos trabalhos de Nuno Porto - que reproduzem ideias de Gilberto Freyre, noções de destribalização, tal como eram concebidas no interior dos discursos políticos e administrativos do Estado colonial, e conferem um estatuto de menoridade ao trabalho de Osório de Oliveira - não invalida que se lhe reconheçam como válidas as propostas de interpretação da ideologia colonial com base em objectos concretos (Museu do Dundo, exposições internacionais de arte cokwe, representações fotográficas). Ou seja, a discordância frontal em relação aos argumentos de Porto acabada de exprimir não belisca o essencial do seu método analítico. Pelo contrário, o mesmo método afigura-se exemplar e, tal como já aconteceu com outros investigadores, merece ser adoptado em trabalhos futuros que procurem analisar a ideologia colonial do Estado Novo, como já aconteceu para o caso de Moçambique (Domingos 2009: 63-120). Por esta razão, ao trabalho de reconstituição do sentido de objectos bem delimitados, entre os quais se inclui o referido álbum fotográfico

19 Nuno Porto (op. cit.: 576): «O livro é dedicado à construção visual da harmonia multirracial. Agrupa 142 fotografias por quatro capítulos: paisagem, tipos nativos, cenas da vida indígena e folclore, não utilizando nenhum modo de contextualização das imagens»; Sandra Xavier (2000: 191-195, maxime 192). 
de 1958, acrescentarei três outros exercícios de contextualização. $\mathrm{O}$ primeiro diz respeito à caracterização do meio intelectual português, tal como foi visto por Gilberto Freyre e vivido por José Osório. O segundo exercício encontra-se na reconstituição de alguns modos da circulação internacional de saberes e formas de arte, que são considerados pertinentes para compreender o álbum em causa. Em terceiro e último lugar, será necessário alargar o âmbito da relação - topada por Freyre e repetida por Porto - entre o tradicionalismo das culturas locais, em risco de extermínio, e o impacto das transformações causadas pela modernização, do Estado colonial ou do capitalismo.

Em Aventura e rotina, Freyre apresentou uma interpretação do meio intelectual português, sobretudo lisboeta. Começou por se referir aos intelectuais, de esquerda e de direita, concluindo com um juízo severo: «Nunca vi tanta inimizade entre intelectuais» (FreYre 1953: 21). Depois, como se procurasse demonstrar que só ele conseguia ultrapassar tais clivagens, descreveu os seus encontros e jantares com vários desses intelectuais, com posições políticas antagónicas. Deste modo, Freyre parecia aspirar ao estatuto do intelectual estrangeiro capaz de estabelecer relações transversais com os seus pares, situando-se acima das suas clivagens. Apesar do convite que recebera para visitar as colónias portuguesas lhe ter sido dirigido pelo Ministro do Ultramar, Sarmento Rodrigues, e de poder ser considerado um convidado oficial para uma missão governamental, Freyre marcou as suas distâncias em relação aos círculos oficiais. A fotografia em desdobrável no início da primeira edição do seu livro, que foi suprimida da edição feita em Portugal alguns anos depois, retratava o autor ao lado de Salazar. A sua longa legenda terá, com certeza, irritado este último. Aliás, quando voltou a Lisboa em Maio de 1957, Salazar não o recebeu, mas fez questão em lhe enviar uma fotografia, «atendendo a um pedido meu» - no seu entender tratava-se de «uma fotografia que honrará nossa casa do Recife onde o Doutor Oliveira Salazar é admirado por três gerações de Freyres». ${ }^{20} \mathrm{O}$ caminho para o apaziguamento estava, talvez, em aberto ou o litígio entre os dois nunca terá sido explícito.

2o ANTT, AOS/CP - 121, fl. 342. 
Figura 4. «Na residência, em Lisboa, do Presidente do Conselho de Portugal: o autor, já pronto a sair, ouve um reparo do Professor Oliveira Salazar, cheio do melhor humour; e quando há humour, pode haver divergência até profunda de ideias»

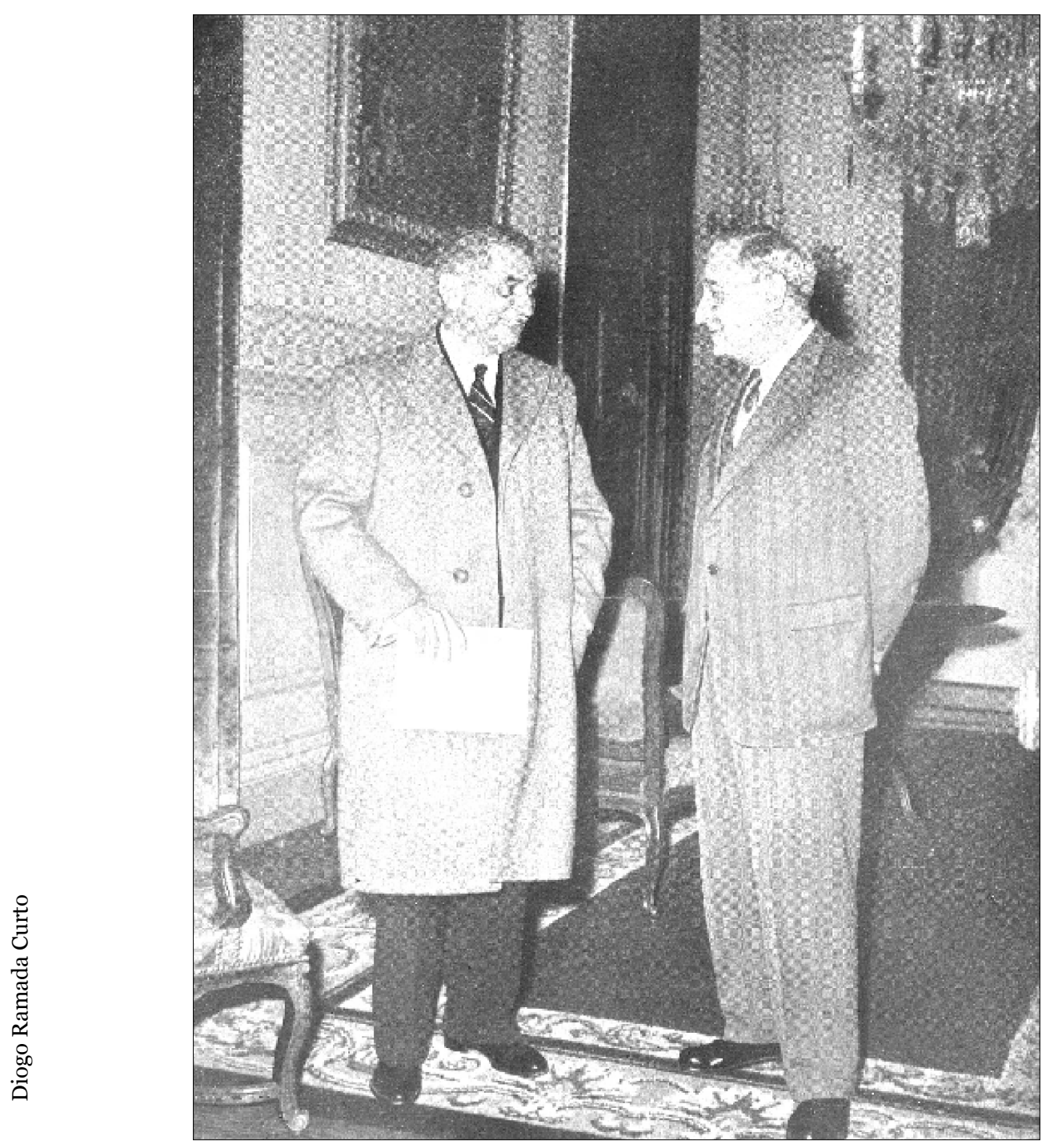

Fonte: Gilberto Freyre, Aventura e rotina: sugestões de uma viagem à procura das constantes portuguesas de caráter e acção (Rio de Janeiro, Livraria José Olympio Editora, 1953).

Gilberto Freyre aspirava a ocupar um lugar situado para além das clivagens locais e, por isso mesmo, negociou - para recorrer a uma expressão do agrado de Nuno Porto e que as ciências sociais 
têm procurado banalizar - também um espaço de dissensão em relação às visões oficiais. Assim, encontrou-se com os seareiros Nuno Simões, que considerava uma instituição devido às relações permanentes que tinha com o Brasil, e com António Sérgio, primeiro num almoço em casa daquele, depois numa visita que o último expressamente lhe fez (FreYre op. cit.: 30-31, 232). ${ }^{21}$ De notar que Maria Archer, nas páginas da Seara Nova, em finais de 1937 (um ano antes da data indicada por Porto), já discutira a obra de Freyre e a sua aplicação a África; a mesma preocupação crítica tivera António Sérgio quando prefaciou Freyre, em edição carioca, a cargo do prestigiado José Olympio (ARCHER 1937: 166-170, 198-200; SÉrGIO 1937: 403-410, maxime 403; Sérgio in FREYRE 1940). Ao narrar a visita a António Sérgio, Freyre acabou por fazer o elenco dos intelectuais portugueses envolvidos no estudo do ultramar, historiadores e não só: António Sérgio e Jaime Cortesão, a que se somavam o jovem Vitorino Magalhães Godinho, Avelino Teixeira da Mota com os estudos histórico-etnográficos da Guiné (a que associava, noutra passagem do livro, António Carreira), Damião Peres, Hernâni Cidade, Luís Silveira, Orlando Ribeiro, João de Castro Osório e José Osório de Oliveira, a quem chamou «os dois Osórios», Mendes Corrêa, o Visconde da Lagoa e Jorge Dias (FrEYre op. cit.: 236). ${ }^{\mathbf{2 2}}$ Trata-se de um elenco suficientemente representativo à esquerda $\mathrm{e}$ à direita, do materialismo económico e social às determinações do social por via das ideias e da cultura. Quanto a encontros com figuras mais próximas do regime, Freyre registou os jantares que lhe foram oferecidos pelo casal Mendes Corrêa, na sua casa de Lisboa, e pelo seu amigo José Osório, o qual juntou na mesma mesa Diogo de Macedo, escultor e crítico de arte, que acomodou bem as suas experiências modernistas, mais ou menos extravagantes, ao Estado Novo, e o poeta Ruy Cinatti - uma tríade cujas vozes estão longe de

${ }^{21}$ Sobre Nuno Simões, para além dos seus livros relativos ao Brasil, veja-se o seu artigo «A lição de São Paulo e o Ultramar Português (Carta a João Sarmento Pimentel)», Seara Nova, ano xvi, n. ${ }^{\circ} 496$ (4-2-1937); a que respondeu João Sarmento Pimentel, «A emigração portuguesa para o Brasil», Seara Nova, ano XVIII, n. ${ }^{\circ} 576$ (27-8-1938), pp. 275-277; e Nuno Simões, «Systema de colonização", Revista do Brasil, ano II, $3 \cdot^{a}$ fase, n. ${ }^{\circ} 11$ (Maio 1939), pp. 37-40.

22 Sobre os trabalhos ultramarinos de João de Castro Osório, ver prefácio a José Luiz Quintão, Gramática de Kimbundo (1934); Idem, A formação orgânica da Expansão portuguesa, sep. de $1 .^{\circ}$ Congresso Nacional de História da Expansão Portuguesa no Mundo (1937); Idem, Direito e dever de império (1938). 
formar um bloco (FreYre op. cit.: 248, 256). ${ }^{\mathbf{2}}$ Mas, também aqui, quanta distância existia entre as visões racistas do médico e grande adepto da antropologia física que era Mendes Corrêa e a ponderação dos aspectos culturais e dos estilos de vida, tão ao gosto do próprio Freyre, de Osório de Oliveira. Uma distância, diga-se de passagem, entre abordagens bem diversas que deixara marcas na correspondência trocada entre Mendes Corrêa e Osório, a respeito tanto da hierarquização racial que obcecava o primeiro, como da posição dos mestiços. ${ }^{\mathbf{2 4}}$

Frente a um campo intelectual do qual Freyre era simultaneamente etnógrafo e parte, quando pretendia reclamar para si uma posição que estava para além das clivagens políticas, será difícil opor um José Osório, monolítico e ortodoxo - ao serviço da propaganda do Estado Novo, funcionário da Agência Geral das Colónias e secretário da revista Atlântico, que na década de 1950 se deixou submeter às lógicas e aos interesses da Diamang. Claro que talvez seja este o problema das análises demasiado individualizadas, é que, ao particularizar os sentidos de uma obra, escrutinando os seus múltiplos sentidos, se descobrem espaços de dissensão, acrescidos de ambiguidades e contradições deliberadas, mesmo em relação aos que tinham a seu cargo a máquina de produção de uma cultura oficial. Também é evidente que será sempre difícil medir ou mesmo encontrar os critérios a partir dos quais podem ser aferidas as vozes dissonantes de uma cultura oficial, sobretudo quando estava em causa a justificação de um projecto colonial, que contava com a participação de muitos outros agentes e instituições pouco propensos a admitir a dissensão.

23 Sobre Diogo de Macedo e os limites do seu interesse pela «arte indígena», cf. Alfredo Margarido (2001: 3-11).

160

24 Biblioteca Nacional de Portugal, Espólios, N 24 - «Espólio de José Osório de Oliveira», n. ${ }^{0} 177$ [Carta de Mendes Corrêa, 1-4-1934: "por uma exigência estatística, falta à sua resposta uma coluna "Qualidades e respostas" a indicação abreviada da sua opinião sobre a posição dos mestiços relativamente às raças originárias para uma das qualidades referidas. Assim entende $V$. Ex. ${ }^{a}$, por exemplo, que o caboverdeano é mais probo e fiel do que o europeu e este mais do que o negro»]. Sobre a questão da mestiçagem Mendes Corrêa foi claro em $O$ mestiçamento nas Colónias Portuguesas. Estudo apresentado ao II Congresso da União Nacional, em Maio de 1944 (1945), p. 8: «Não deve considerar-se o mestiçamento em larga escala como base da nossa política colonial, pois isso implicaria a destruição de um património germinal, que é a maior garantia da continuidade histórica da Pátria». 
Entre os modelos - muito em particular dos estilos de vida, das formas de representação ou de conhecimento - que circularam em Portugal durante o Estado Novo, os relativos ao Brasil foram, talvez, os que tiveram maior impacto na definição das políticas coloniais. Assim, qualquer esforço de análise das lógicas internacionais, em que se inserem os projectos coloniais portugueses, terá de incluir, para além do papel desempenhado pelas instituições internacionais propriamente ditas e da circulação dos modelos de colonização lançados por outros Estados coloniais europeus, a discussão acerca do modo como o Brasil assumia uma relevância central - a ponto de se querer fazer novos Brasis em África... A este respeito, o sentido da obra de Gilberto Freyre começou por ser alvo de um elogio muito precoce, em 1933, logo no ano da publicação de Casa Grande \& Senzala, por parte de José Osório de Oliveira, no quadro de uma defesa da colonização portuguesa e da mestiçagem:

«Não se pode afirmar que o cruzamento das raças tenha obedecido a um princípio de colonização, mas também não se pode dizer que ele tenha sido apenas um produto da luxúria dos portugueses. $O$ nosso amor pelas raças chamadas inferiores fez dizer a um escritor brasileiro a frase mais bela que tenho ouvido sobre os portugueses. Esse brasileiro, Gilberto Freyre, dizia-me um dia que, depois de Cristo, ninguém tinha contribuído mais do que nós para a fraternidade dos homens. Corroborando a minha opinião sobre a excelência do mestiço nos climas tropicais, dizia-me ainda esse escritor que na sua terra - Pernambuco - o mulato é quem mais trabalha e quem revela mais energia» (OLIVEIRA 1933: 47-48).

Mas, foi sobretudo a partir de 1937, que a obra de Gilberto Freyre passou a ser discutida à esquerda e à direita, respectivamente, pelos já referidos Maria Archer, António Sérgio e Nuno Simões, nas páginas da Seara Nova, bem como por José Osório de Oliveira, João de Barros e Gastão de Bettencourt, numa edição de luxo, com extenso aparato fotográfico em papel couché, a sugerir a modernização do Brasil e das suas cidades (BARros, Oliveira, Bettencourt 1938: maxime 46; Barros 1946; Bettencourt 1954). Por sua vez, muito mais racista e eugenista, Mendes Corrêa mostrou a sua predilecção pelas visões de Oliveira Viana, que Osório também conhecera 
(CORRÊA 1935). ${ }^{25}$ Também o coronel e legionário Alexandre de Morais publicou, em 1942, uma volumosa obra sobre o Brasil (MORAES 1943). Foi, igualmente, neste contexto que Stefan Zweig publicou em Petropólis, Brasil. País do futuro.

Em 1938, nas páginas da Seara Nova, ao fazer o elenco dos intelectuais brasileiros que estudavam o Brasil, Nuno Simões, pondo de lado os escritores de obras literárias, colocou no centro, como «animadores e jovens mestres», Gilberto Freyre e Artur Ramos (SIMÕES 1938: 204-207, maxime 204). Em 1943, foi a vez de José Osório publicar uma antologia bastante diversificada e atenta ao legado africano de ensaístas brasileiros (Oliveira 1943). Em 1952, o mesmo prefaciou a edição portuguesa de uma súmula do pensamento de Freyre (FreYre 1951). E, no mesmo ano, dedicou aos referidos Freyre e Ramos a sua Contribuição portuguesa para o conhecimento da alma negra. É pouco argumentar que a circulação por Portugal da obra de Freyre, com discussões críticas e declarações de admiração à mistura, se fez tanto à esquerda como à direita. No caso de José Osório, pelo menos, a obra do intelectual pernanbucano servia - tal como a de Mário de Andrade - para justificar uma articulação entre a qualidade literária propriamente dita e a profundidade dos seus estudos e ensaios. Declarou-o Osório, ao julgar os trabalhos de etnógrafos e geógrafos como Leite de Vasconcelos, Orlando Ribeiro e Jorge Dias. Em sua opinião, estes não alcançavam o público, «mesmo só o público intelectual»; pois, faltava-lhes «a arte literária de um Gilberto Freyre, que lhe permite interessar todos os leitores de língua portuguesa num estudo ecológico circunscrito a parte de uma zona do Brasil, como é o da influência da cultura da cana de açúcar sobre a vida e a paisagem do Nordeste agrário» (OLIVEIRA 1949: 83).

25 Biblioteca Nacional de Portugal, Espólios, N 24 - «Espólio de José Osório de Oliveira», n. ${ }^{0} 507$ [Carta de Oliveira Viana, s.d., agradece a bem ordenada entrevista que José Osório lhe fizera no Diário de Notícias: «Bem razão tinha o seu amigo e companheiro quando me dizia que o senhor era realmente admirável neste género difficilimo da arte literária»]; José Júlio Rodrigues, O Brasil... de relance, pref. do Doutor Mendes Corrêa (1941), pp. 153-156 [queixa-se do desconhecimento existente em Portugal acerca dos intelectuais brasileiros e dos seus trabalhos, maxime 153. "desconhecemos (e não só a média classe da minha terra, até em certo ponto a elite) bem setenta por cento dos melhores valores brasileiros de hoje»]. 
Os estudos sobre a língua, a literatura e o ensaísmo etnográfico do Brasil, enquanto modelos, circulavam por Portugal. José Osório conhecera Mário de Andrade, em 1923, um ano depois de ter tido lugar a Semana de Arte Moderna de São Paulo. Participou nas reuniões em sua casa da rua Lopes Chaves. No epitáfio que lhe dedicou, na altura da sua morte, lembrou - talvez numa projecção ou na fixação de um modelo a que ele próprio aspirava - que tais reuniões não eram «campo de lutas políticas» - «tudo, nessa casa, falava de outras paixões mais duradouras: a literatura, as artes plásticas e a música» (idem 1957: 30). Numa outra evocação do amigo, versado em tantos géneros, Osório voltou à carga e citando António Candido, sublinhou: "A sua correspondência encherá volumes $e$ será porventura o maior monumento do género em língua portuguesa» (idem 1947: 106-108, maxime 107). Já em 1933, escrevia que Mário deveria ser reconhecido não só como poeta e teorizador do modernismo literário, mas também como «notável musicógrafo e folclorista» (idem, op . cit.: 56, 91-92). Numa palavra, era enorme o fascínio que Osório sentia pelo modo como o autor de Macunaíma articulava a sua participação no vanguardismo modernista com os estudos etnográficos e folcloristas das músicas e das danças brasileiras de origem africana (idem, 1942: $31-38){ }^{26}$

São vários os casos de outros intelectuais que, em contacto com o Brasil de Mário de Andrade, Artur Ramos e Gilberto

26 «Resumo do Brasil, para Portugueses», maxime pp. 32-33: «Onde estudar esse estilo de vida próprio do Brasil? Não será, com certeza, na história política, que só se preocupa com os nomes dos heróis ou dos estadistas, e com as batalhas ou as mudanças de regime governativo. Pode sê-lo, porém, na história social e cultural, que se interessa pelas formas de organização social, pelos sistemas de exploração da terra, pelos consequentes modos de vida, que se reflectem na época contemporânea, servindo de explicação à geografia humana. Faz-se essa história, não com o auxílio dos documentos escritos, não com os vestígios oficiais do Passado, mas com a etnografia, por exemplo, ou, particularmente, com o folclore. Com livros de receitas de doces caseiros, tradicionais, pôde Gilberto Freyre reconstituir, por assim dizer, as vidas das casas-grandes dos engenhos de açúcar e toda a sociedade patriarcal dos tempos do trabalho escravo e da monocultura latifundiária de Pernambuco. Escrevendo com o espantoso Macunaíma, uma rapsódia do folclore variado e heterogéneo do imenso Brasil, Mário de Andrade pôde, não só dar à literatura brasileira a sua obra mais original, como fornecer o retrato moral mais exacto do povo a que pertence, porque ofolclore lhe mostrou o caos de ideias e de sentimentos em que vive esse povo, tal como o seu herói sem nenhum carácter». O mesmo fascínio por Mário de Andrade e Macunaíma encontra-se em Carlos Queiroz (1940: 54-56). 
Freyre, procuraram articular dimensões acerca de África e das culturas locais que, à primeira vista, pareciam opostas. Entre nós, o pouco conhecido etnomusicólogo, filólogo e historiador da escravatura Edmundo Correia Lopes constitui-se num caso que está ainda por estudar. ${ }^{27} \mathrm{O}$ seu dinamismo e perspectivas inovadoras, algumas delas claramente estabelecidas com o apoio de Osório de Oliveira, cruzaram-se com a criação do Centro de Estudos da Guiné Portuguesa - pelo governador Sarmento Rodrigues, com o apoio de Avelino Teixeira da Mota e António Carreira -, orientado para «o estudo do que diga respeito aos valores indígenas, das suas artes primitivas, das suas línguas, costumes e tradições, de tudo que possa registar uma existência, uma personalidade que o tempo fatalmente destruirá». ${ }^{\mathbf{2 8}}$ Os interesses de Edmundo Correia Lopes coincidiam, aliás, com um dos que mais mobilizou pesquisadores universitários franceses, ingleses e norte-americanos que, entre 1930 e 1968, viajaram e pesquisaram sobre o Brasil. Refiro-me aos estudos

27 «À memória de Edmundo Correia Lopes», Boletim Cultural da Guiné Portuguesa, vol. III, n. ${ }^{\circ} 12$ (Outubro 1948), pp. 1037-1062.

28 Edmundo Correia Lopes (1946: 1-8); Comandante M. M. Sarmento Rodrigues (1952: 161-168): «No domínio cultural - Discurso na primeira reunião magna do Centro de Estudos da Guiné Portuguesa - Bissau, 9 de Novembro de 1946», maxime 165; António Duarte Silva (2010); Clara Carvalho (2004: 119145); Clara Carvalho (2008: 145-173); Carlos Manuel Valentim (2007: 32-33); Instituto de Investigação Científica Tropical, Centro de Estudos de História e Cartografia Antiga, Espólio do Almirante Avelino Teixeira da Mota, Pasta 750 [Carta de António Carreira a A. Teixeira da Mota, 12-2-1948, cit. por Carlos Manuel Valentim (2005), p. 35: «O Mota pode vangloriar-se de haver conseguido com a sua inteligência, dedicação e persistência, aquilo que muitos outros quiseram tentar e desistiram. A obra do Governador, no campo cultural, pertence-lhe. Sem o Mota ele não a realizaria, plena de êxito e admirada como é. Todas as publicações da Colónia, nomeadamente o Boletim, falam eloquentemente a marcar uma época como nenhuma outra. No dia em que o Governador deixar de dirigir a Colónia e V. vier em definitivo para a Metrópole, tenciono, então, fazer um balanço geral do que foi a Vossa actuação e o que ela se projecta para além do que muitos não vislumbraram ainda. Com todas as virtudes e defeitos (terá mesmo defeitos porque são dos mortais) ela perdurará na memória de todos e vincará um período de Governação que não pode sofrer apreciação, por confronto, com outros anteriores - foi de todos o mais brilhante»]. Nos cadernos de campo da Missão Geográfica de 1947, Orlando Ribeiro - nos seus Cadernos de campo Guiné 1947 (HavicK e DAVEAU, eds., pp. 97-98) - registou: «Diz o velho colono - não se planta nada, porque ninguém se importa nem o gov. favorece. A colónia vive do trabalho indígena - por isso é essencial tratá-lo bem, porque sem ele a colónia não vive. Aqui pediram auxílio ao governo de coisas de técnica agrícola e não receberam auxílio nenhum, ou tardio e insuficiente». 
das práticas religiosas afro-brasileiras, candomblé e umbanda, que foram dos mais importantes, a par da questão das relações raciais; investigações centradas sobretudo na Bahia e na grande metrópole de São Paulo, promovidas por programas universitários e protagonizados por Bastide, Pierson, Willems, bem como Charles Wagley e Marvin Harris (estes últimos com o apoio da Universidade de Columbia, outros graças à Unesco, onde Alfred Métraux assumiu na década de 1950 posição de direcção, foram dos mais importantes). Ora, todos estes trabalhos de pesquisa, ancorados disciplinarmente sobretudo na antropologia e na sociologia, romperam com a tradição do ponto de vista ensaístico (Pontes in Miceli 1995: 441-477, maxime 446-457).

Blaise de Cendrars foi quem melhor compreendeu a mudança, que estava em curso, nos modos de conhecer o social. Ou seja, percebeu bem o modo como se anunciava uma ruptura científica - sociológica, entenda-se - , à qual reagiu com palavras de uma enorme perversidade. Cendrars, que visitou sete vezes o Brasil entre $1924 \mathrm{e}$ 1935, procurou ali a já referida articulação entre pólos opostos de conhecimento: da selva amazónica às grandes cidades de São Paulo e Rio de Janeiro. O mesmo sucedeu com as experimentações, de uma outra variedade de géneros, que incluíram o projecto de um filme, cujo guião datava de 1929, mas de que resultou apenas um álbum fotográfico sobre o Brasil, publicado em 1952, e esse monumento literário que foi a tradução parafrástica de $A$ Selva de Ferreira de Castro. Esta última terá sido feita com o provável auxílio de Osório de Oliveira, com o qual se correspondeu e encontrou numa das suas passagens por Lisboa (WARNIER 1973: 15-31; RoIG 1988: 273-298, maxime 278-281). ${ }^{29}$ Ora, Blaise de Cendrars - ao lado de Mário de Andrade - não representava apenas uma outra maneira de conciliar o vanguardismo modernista do Brasil com a selva amazónica. Os seus interesses ou experiências pelas zonas sombra do primitivismo incluíam as literaturas e culturas africanas, tal como ficara demonstrado na sua Anthologie nègre (1921). Ora, foi esta última obra que inspirou alguns dos projectos de José Osório, relativos ao estudo das literaturas africanas (OLIVEIRA 1944; 1962, 2. ${ }^{\text {a }}$ ed.).

29 De notar que o álbum fotográfico sobre o Brasil de Cendrars, é publicado um ano depois (talvez como resposta?) do de Antoine Bon, M. Gautherot e Pierre Verger, com pref. de Alceu Amoroso Lima (1951; 1952). 
Último exercício de contextualização: como eram pensadas as relações entre culturas locais, em risco de extermínio ou de serem reduzidas a uma espécie de arcaísmo, e o impacto da modernização, causada pelo Estado colonial ou pelas empresas capitalistas? A este respeito, não sei se os interesses de Blaise de Cendrars pelo funcionamento de uma plantação capitalista do Estado de São Paulo, com mais de dois mil trabalhadores, tiveram uma influência directa em Osório, quando também ele se veio a interessar por uma companhia que controlava uma área de cerca de 1/3 de Portugal, onde trabalhavam cerca de 332 europeus, acompanhados por 417 mulheres e crianças, e cerca de 17.000 indígenas (em 1959, estes mesmo números subiam para 23.903, com um acréscimo de 355, em relação ao ano anterior, com a informação de que cerca de dez mil eram recrutados no Songo) (LeAL 1960, III: 31). Porém, para Cendrars, tal como para Mário de Andrade, as ideias de experiência, de literatura vivida e do seu envolvimento directo, presencial, com o terreno - quer este fosse o do primitivismo das culturas africanas, quer o do vanguardismo modernista - faziam parte integrante do que hoje tendemos a designar pomposamente como projecto literário (RoIg 1979: 133-156; 1988; VILHENA 1955: 18, 30). Mais. A conjugação de várias formas de expressão e comunicação - das artes plásticas à rádio, da fotografia ao cinema - também se afigurava uma constante. E, mesmo que seja difícil reconstituir as filiações ou influências, tem de se reconhecer que o escritor José Osório participou - porventura, com um certo atraso em relação aos exemplos de Andrade e Cendrars - dos mesmos cruzamentos entre géneros tão díspares e opostos. Talvez, por isso mesmo, tivesse sentido a necessidade de saltar da literatura de escritores e intelectuais do Brasil e da África, nomeadamente de Cabo Verde, para a cinematografia, a escultura chokwe, as recolhas de música africana, a fotografia, a reflexão sobre o Museu do Dundo, o pensamento e a acção em situação colonial. E, tal como sucedeu com Mário de Andrade e Gilberto Freyre, Osório procurou conciliar o ensaio com o cuidado pela forma estética literária. Neste sentido, mais do que se falar numa intenção ideológica em que o carácter primitivo, arcaico ou tradicional das culturas nativas da Lunda, em processo de exterminação, contrasta com a imposição de uma ordem moderna capitalista e colonial, não será melhor falar de um projecto estético e literário que unia esses dois lados como fazendo parte da mesma moeda? 
Se esta interrogação contém em si uma hipótese que serve de conclusão a estas breves notas exploratórias em torno de um álbum fotográfico, são inúmeras as pontas do emaranhado de fios que ficam por atar. Antes de mais, importa reconhecer que pouco se sabe acerca da distinção proposta por Osório entre a arte chokwe, pela qual se interessou, e a ideia generalista de primitivismo associada à arte indígena, tal como ela se tinha começado por configurar cerca de duas décadas antes, numa exposição e num catálogo organizado pelo seu amigo Diogo de Macedo (MARGarido 1972: 491-504; 2001: $3-11) .^{30}$ Depois, será necessário não confundir o sentido estético e literário do projecto de Osório, quando procurou conjugar, para simplificar, primitivismo com vanguardismo; fazendo confluir as atitudes - porventura mais históricas, antropológicas, jurídicas e administrativas - em relação ao modo de articular culturas indígenas com processos de modernização. A este respeito, nunca será demais recordar que a abolição, em 1961, do Estatuto do Indígena com tudo o que implicava de regimes de trabalho forçado, trabalho compelido ou a contrato - coincidiu com a promulgação do diploma legal que instituiu as regedorias. Ou seja, coincidiu com a transformação dos sobas em colaboradores juridicamente reconhecidos do Estado colonial, no interior do qual os próprios chefes ditos tribais passavam a figurar como o elo mais baixo da hierarquia. Isto é, a modernidade associada à abolição do estatuto do indígena foi compensada pelo reconhecimento das regedorias, com os seus sobados, tribos e culturas nativas tradicionais. Nesta mesma sequência, num contexto homólogo, se deverá entender o facto de Jorge Dias - ao estudar uma cultura tradicional como a dos Macondes, com propósitos que podiam ser os de reconhecer informações sobre um grupo mal integrado - só de passagem referir que uma parte deste grupo já estava integrado, por via da emigração, nos mercados economicamente mais desenvolvidos da Tanganica, e que, por isso mesmo, se encontravam bem longe dos ritos e costumes tribais com que os mesmos eram identificados no seu livro (DIAS, I, 1964).$^{\mathbf{1 1}}$

30 Tema que deverá ser problematizado com base em E. H. Gombrich (2002).

${ }^{31}$ Sobre as mesmas migrações, cf. Edward Alpers (1984: 367-388). Tal como já foi notado, «apenas poucos ou nenhuns dos macondes vivos na altura em que a pesquisa de Dias levou a cabo a sua pesquisa viviam de facto segundo a "tradição maconde", descrita em Os Macondes de Moçambique», tal como certeiramente notou Harry G. West (in SANCHES 2007: 141-190, maxime 152). 
Porventura mais importante, será ainda integrar o debate entre Gilberto Freyre e José Osório no contexto internacional posterior à Segunda Guerra. A declaração intitulada Unesco Statement on Race de 1950 e a multiplicação das investigações brasileiras sobre a variedade regional das relações raciais estabeleciam termos que extravasavam a simples antinomia entre aqueles dois autores e a possibilidade de uma redução a versão adocicada versus perspectiva racista (MAIO 1999: 141-158; BRATTAIN 2007: 1386-1413). De igual modo, em Cabo Verde, pela mão do escritor e intelectual Baltasar Lopes também se assistiu a uma crítica dura aos métodos de observação de Gilberto Freyre: que teria estado pela Praia um mês, em Outubro de 1951, tendo dali partido para S. Vicente, onde assistiu apenas a uma ou outra manifestação de «folcore urbanizado»; e continuou unicamente a «arranhar o litoral», sem conhecer a diversidade das culturas de Cabo Verde, quando tocou no Sal; entre outras coisas, não entendeu, porque não chegou a observar, «o sistema de trabalho rural, o binómio proprietário-rendeiro, o nútido sentimento aristocratizante de sentido europeu de classe não rural, a diluição de África» (Lopes 1956: 7-8). ${ }^{32}$ Por último, será necessário perceber melhor de que modo o projecto estético dos intelectuais fascistas e nazis, na identificação do folclore e na etnografia de grupos primitivos, se cruza com o interesse do neo-realismo pelo povo e pela compreensão das culturas tradicionais (FERREIRA, op. cit.: LXXXVII). Claro que é mais fácil exprimir entusiasmo ou abertura em relação ao interesse dos escritores neo-realistas. E qualificar de puro oportunismo ou de falta de escrúpulos éticos e estéticos os que puseram os seus projectos literários ao serviço de regimes totalitários (Molina 2014: 3).

32 Republicado na antologia do autor, Escritos filológicos e outros ensaios, com biografia de Arnaldo França e estudo de Alberto Carvalho (2010: 229-275, maxime 233-234). Por outros motivos, a dúvida relativa ao modo como Gilberto Freyre observou Cabo Verde, quando este considerava que as suas populações eram "predominantemente africanas», encontra-se em P.e António Brásio (1962: 85): «Afirmar que o cabo-verdiano é um mestiço mais africano do que português, parece-nos afirmação gravemente errónea justamente no aspecto sociológico». 
Uma simples comparação dos tipos de fotografias que constam dos Relatórios da Companhia dos Diamantes entre 1938 e 1940, com o álbum de José Osório, coloca a questão de saber porque desapareceram deste último as representações do trabalho indígena nas minas, nos movimentos de terras para remoção do estéril, e no transporte de vagões. ${ }^{33}$ Não seria simplesmente porque a estética almejada no álbum era incompatível com a brutalidade da exploração dos corpos africanos, muitos deles adolescentes, conforme constam das representações fotográficas que acompanham os relatórios? A questão, só por si, sugere a existência de muitas outras clivagens e os trabalhos de investigação histórica e antropológica, centrados na busca de sentidos culturais e na compreensão das mensagens ideológicas, deverão procurar situar as clivagens umas em relação a outras, incluindo as que assumiram contornos de carácter económico e militar, porventura mais pertinentes e com um alcance mais global. É que existiram muitas outras clivagens em torno da Companhia dos Diamantes, as quais alcançaram uma intensidade exemplar ao longo da década de 1950. Clivagens, aliás, que nada tiveram que ver com a discussão acerca dos modelos ideológicos que opuseram Freyre a Vilhena. Clivagens, acrescente-se, que nos fazem recordar que as abordagens demasiado centradas em questões ideológicas e das representações, ditas culturais, não poderão fazer esquecer a força determinante assumida pelos interesses económicos. Ora, essas outras clivagens diziam respeito aos modelos de negócio implicados pelo comércio, mais do que pela produção, dos diamantes.

A primeira das clivagens a ter em conta diz respeito ao modo como os lucros da Companhia se distribuíam entre os seus accionistas, em relação ao modo como o Estado colonial e Angola em particular poderiam tirar partido dos mesmos rendimentos, sob a forma de imposto ou outra qualquer cobrança. ${ }^{34}$ Durante a Segunda Guerra, as tentativas alemãs para furar o monopólio do contrato

$33 \mathrm{AOS} / \mathrm{CO} / \mathrm{UL} / 8 \mathrm{~A} 3$, fls. 8, 20, 22, 103.

34 Aos/Co/Ul-21, Pt.1, fls. 1-2v (Carta da Société Générale de Belgique, Bruxelas, 8-11-1937, que traça bem a referida clivagem); AOs/Co/UL-21, fls. 475-479 (Carta do Subsecretário de estado do Ultramar, Varela, que traça as tensões entre Governo e Governador Geral sobre a participaçção nos lucros, 21/10/1954). 
da Companhia dos Diamantes com a Diamond Corporation foram suscitadas sobretudo pelo lado alemão. Para além dos aspectos económicos envolvidos na preocupação em pôr em causa «o monopólio inglês do diamante», por parte dos nazis, estes aspiravam a poder anunciar, para fins políticos e de propaganda de guerra, a destruição de um tal contrato. ${ }^{35}$ Mas no período posterior à Segunda Guerra, surgiram outras clivagens, pois não pode ser escamotedo o facto de que os rendimentos brutos e fiscais de Angola, mau grado os esforços já feitos na produção do café, continuavam a ter nos diamantes o seu principal produto. ${ }^{\mathbf{3 6}}$ De um lado, estava a denominada The Diamond Corporation Limited, com capacidade para monopolizar o negócio da lapidação e comércio, cujos representantes principais eram o grupo De Beers e Sir Ernest Oppenheimer pela União Sul Africana. De facto, a produção diamantífera da Diamang foi, até 1864, totalmente exportada para o Reino Unido (Neto 1991: 86). No seu modo de actuar The Diamond Corporation, não se escondia a ligação permanente aos governos da África do Sul, Grã Bretanha e Portugal, recorrendo ao Lloyds Bank para as transferências - «we in London are in continuous communication with our respective Governments», escrevia o seu director de Londres para a Companhia dos Diamantes em Lisboa, em 1951. ${ }^{37}$ Do outro lado, posicionaram-se os que pretendiam furar o referido monopólio, aliando-se a outras casas londrinas, mas argumentando que só assim se poderia criar em Portugal o maior centro de lapidação e comércio de diamantes. Estavam, neste último grupo, figuras conhecidas da oligarquia do regime salazarista, tais como Casal Ribeiro, Francisco de Mello Breyner (Conde de Mafra) e Dinis Bordalo Pinheiro. Estes não pretendiam pôr em causa a Companhia dos Diamantes de Angola, mas articular-se com ela. Existiram, também, tentativas norte-americanas, mediadas pela respectiva embaixada, em 1951-1952, destinadas a pôr em causa relação contratual

35 AOS/Co/Ul-8A 3, fl. 166: «Relatório apresentado pelos adminsitradores por parte do governo na Companhia de Diamantes de Angola. Relativo aos anos de 1939 e $1940 »$, p. 5 .

${ }^{36}$ Boletim da Junta de Exportação da Colónia de Angola (n. ${ }^{\circ}$ 4, Luanda, Fevereiro 1950: 5). Trata-se de um número de uma publicação periódica incluído num dossier relativo à actuação do Ministro das Colónias Teófilo Duarte e que acompanha o relatório do seu governo, enviado a Salazar em 1950, f. AOs/co/ UL-19, fl. 203.

37 AOS/CO/UL-22, fls. 188-190. 
de exclusivo que a Companhia dos Diamantes de Angola mantinha com a referida Diamond Corporation, localizada em Londres. Com a intervenção pessoal directa de Salazar, procurou-se uma solução de compromisso, destinada a satisfazer os interesses dos Estados Unidos, em termos do fornecimento de diamantes industriais.

Mas a clivagem mais importante foi a que opôs Harry Winston - norte-americano que tinha ligações às minas de diamantes da Tanganica - a Ernest Oppenheimer, na disputa pelos diamantes de Angola. Conforme resume Cunha Leal, as minas da Tanganica tinham rompido com a sumsissão ao empório de Oppenheimer, por decisão do seu concessionário John Thorburn Williamson, mas com a morte deste último, em 1958, a De Beers acabou por tomar posição e restabelecer o seu monopólio (LEAL 1960: 33). Winston queixava-se de que lhe tinham sido cortados os fornecimentos de diamantes, por parte da Diamond Corporation, e declarou o seu total apoio a Salazar, comprometendo-se a desenvolver em Portugal uma indústria de lapidagem para os diamantes de Angola e da Tanganica. Em 1952, Harry Winston manteve correspondência directa, com o Professor João Pinto da Costa Leite (Lumbrales), a quem trata por «Dr. Lumbrellish», Ministro da Presidência. Porém, são as cartas do próprio Winston - cheias de confidências, de referências a telefonemas e de pedidos de informação acerca do seu projecto de uma indústria da lapidação em Portugal - com o banqueiro Ricardo Espírito Santo Silva, datadas de 1954, cujos originais se encontram no próprio Arquivo Salazar, que esclarecem o grau de penetração dos interesses económicos na política do Estado Novo, bem como o modo como o próprio Salazar geria pessoalmente os mesmos negócios, na base de relações clientelares e pessoais.

No caso em apreço, não parece que a pressão do banqueiro sobre o ditador tenha surtido efeito, uma vez que as estreitas relações da Companhia dos Diamantes com a Diamond Corporation ficaram na mesma - e o banqueiro não obteve a almejada comissão. Nos meios oficiais portugueses, sabia-se que os métodos da Diamond Corporation levavam a que, sempre que surgia um concorrente interessado em furar o seu monopólio, o preço dos diamantes baixava, para que se pudesse restabelecer o chamado «one-channel system», ou seja, o monopólio nas vendas e distribuição controlado pela Diamond Corporation. Não terá sido a viagem de Craveiro Lopes, Presidente da República, ao Dundo, em meados de 1954, um modo de reiterar 
essa situação de inércia ${ }^{\mathbf{3}^{8}}$ Parece que sim, a ter em conta que outras propostas de mineração e de lapidagem, em Angola, circularam pelo gabinete de Salazar, mas sem nunca ousar beliscar os interesses criados pela Companhia dos Diamantes. ${ }^{39}$ Ao lançar a Sociedade Portuguesa de Lapidação de Diamantes, o Comandante Ernesto Vilhena referiu, numa carta de Abril de 1958 enviada a Salazar, "as razões que nos levaram a não querer abandonar a "Corporation" que, fácil, talvez, de substituir em períodos de prosperidade, nos faria grande falta quando a pobreza nos batesse à porta». ${ }^{\mathbf{4}}$

Bem pôde, por isso, Cunha Leal atacar a Companhia dos Diamantes, sobretudo pelo modo como a administração - representada pelo administrador delegado, comandante Ernesto Vilhena, e pelo seu advogado, Azeredo Perdigão - não maximizava os seus lucros, para os distribuir pelos pequenos accionistas. No seu entender, havia incompetência e laxismo, quando se admitia que fossem os intermediários estrangeiros a auferir os maiores lucros; em paralelo com o facto de os próprios corpos gerentes serem contemplados com remunerações fabulosas. O problema, no seu entender, estava no facto de que a gestão não era suficientemente eficaz e moderna. Tratava-se de uma visão que relativizava os aspectos mais propriamente culturais. Embora se possa acrescentar que Cunha Leal não deixava de reconhecer que «os corifeus dos corpos gerentes da Diamang nos apontam, com superlativa admiração, a obra de progresso e de cultura que por eles vem sendo levada a cabo na longínqua Lunda» (LEAL, I, 1957: 47). Considerava, ainda, Cunha Leal que, ele próprio, desde 1956 tinha reconhecido o valor dessa obra que ia da higienização dos aldeamentos indígenas, ao ensino, recolha do folclore local, organização de «sessões gratuitas de cinema recreativo e educativo», "e cuidados para com as populações aborígenes» (idem, II, 1959: 36-37). Porém, mau grado essa obra civilizacional e cultural, impunha-se reconhecer os verdadeiros

38 ANTT, AOS/CO/UL-30, 9. ${ }^{\circ} \mathrm{Sub}$.

39 ANTT, AOS/CO/Ul-2O, n. ${ }^{\circ}$ 20, fls. 420-427; ANTT, AOS/CO/Ul-22, n. ${ }^{o}$ 8, fls. 341-345 (proposta de Sousa Lara, Batalha Reis, Tavares de Carvalho e outros, 24/1/1953); AOS/CO/UL-21, fls. 195-197 (Criação de uma sociedade luso-belgaalemã, com a participação do Dr. Vieira Machado e o Comodoro Lopes Alves, destinada a estudar explorações mineiras e outras actividades, 18/6/1953).

40 ANTT, AOS/CO/UL-38, P. 1, fl. 15. 
problemas: a Diamang actuava numa zona de fraquíssima densidade populacional onde se constatava uma enorme debilidade da sua população. Ora, a mesma Companhia nada fazia para melhorar o «tipo humano local» e para atrair as populações dos territórios circunvizinhos - a densidade populacional continuava mesmo a diminuir devido à emigração para o Congo Belga (idem, idem, II: 39). A esta série de denúncias, acrescentava-se o facto de Cunha Leal considerar que Ernesto Vilhena tratava com uma enorme arrogância a possibilidade de se estarem a infiltrar na Lunda movimentos ditos subversivos. Pois, este último não deixava de afirmar que a Diamang dispunha dos seus próprios meios de combate, considerando que a Diamang estava preparada «para fazer face a uma tentativa dessa espécie» (idem, op. cit.: 32). Outras clivagens existiram. Por exemplo, voltando a recuar a 1953, em que Gilberto Freyre publicou no Brasil o seu relato de viagem pelo Império português e a descrição da sua visita à Lunda, verifica-se que, nesse mesmo ano, Franco Nogueira viajou pela primeira vez por África, mais concretamente por Moçambique. Aquele que veio a ser Ministro dos Negócios Estrangeiros em 1961, revelou nessa mesma data a consciência aguda das questões de defesa militar e as necessidades de efectuar uma aliança internacional, tendo em vista a defesa das colónias europeias em África. Num relatório interno do mNE que chegou a Salazar, descreveu a conversa havida com um representante militar francês - pejada de comparações acerca dos recursos militares belga, francês e inglês - e constatou que os dois pontos por onde a guerra iria começar seriam o Norte de Angola, junto à foz do Zaire, e o aeroporto da Ilha do Sal. Em relação ao primeiro, especificou, "é importantíssimo: quem dominar a foz do Zaire domina ou ao menos neutraliza a África Equatorial e, consequentemente, paralisa o esforço de guerra que aí se pode preparar (não se esqueça a riqueza da região, as suas minas, etc.)». ${ }^{\mathbf{4 1}}$

Enfim, quando em 1959, os membros do Conselho Orientador do Centro de Estudos Políticos e Sociais, dirigido por Adriano Moreira, foram chamados a depôr acerca das medidas a tomar em relação às políticas coloniais, exprimiram pela voz de Martins de Carvalho algum cepticismo em relação a alguns estudos, representativos de certas tendências. Martins de Carvalho, então Ministro da Saúde

${ }^{41}$ ANTT, AOS/CO/UL-61, Pasta 11, fl. 246. 
e Assistência, mas membro do referido Conselho, era talvez o que mais dúvidas tinha em relação aos estudos sobre movimentos associativos em África, da responsabilidade de Silva Cunha. Assim, num relatório considerado secreto, procurou dividir as águas, declarando que a questão da definição das políticas coloniais não estava propriamente no estudo das seitas tendo em vista a sua repressão. Pelo contrário, em relação a tais seitas, a política colonial deveria ser orientada «mais no sentido da absorção do movimento do que no da repressão»..$^{\mathbf{2}}$ Para o Conselho e, muito provavelmente para os que tinham dúvidas acerca da orientação científica, com as suas dimensões antropológica ou sociológica, a questão essencial passava pela revisão da «generalidade dos problemas das relações de trabalho», incluindo a necessidade de encarar «o problema da repressão das explorações de que o indígena africano é vítima, não só por parte de alguns patrões como dos comerciantes do mato». ${ }^{\mathbf{4 3}}$ Ora, segundo o mesmo relatório, "a melhor forma de contrariar a acção dos referidos movimentos consistirá em modificar o condicionalismo económico e social existente em relação a determinadas camadas da população africana, pois é da subsistência das situações internas de injustiça - mais do que da acção exterior que advêm os maiores perigos de subversão da harmonia racial $e$ da tranquilidade social das províncias portuguesas em causa». ${ }^{\mathbf{4}}$

Neste sentido, o mesmo relatório exprimia uma clivagem clara entre os cientistas sociais e os políticos dotados de bom senso e sentido prático em matérias económicas e sociais. À primeira vista, parece que Martins de Carvalho e aqueles que o secundavam punham no mesmo saco Silva Cunha e Adriano Moreira, incentivador dos mesmos estudos científicos. Porém, uma tal clivagem não se terá mantido, nem revelado propriamente um confronto entre dois blocos. Ao longo da década de 1960, as oscilações na ocupação da pasta do Ministério do Ultramar, por Adriano Moreira (1961-1963) e Silva Cunha (1965-1973), e a necessidade daquele se retirar no seu Instituto Superior de Ciências Sociais e Política Ultramarina parece que geraram novas divisões, a começar por aquela que opôs essas duas figuras. A este propósito, como interpretar um ataque tão raro quanto frontal às ideias de Silva Cunha - tidas como «improceden-

\footnotetext{
42 ANTT, AOS/CO/UL-61, Pasta 21, fl. 523.

43 ANTT, AOS/CO/UL-61, Pasta 21, fl. 519.

44 ANTT, AOS/CO/UL-61, Pasta 21, fl. 525.
} 
tes» ou um «evidente equívoco» -, numa tese de doutoramento dedicada a Adriano Moreira, da autoria de Afonso Mendes? (Mendes 1965: 167). Será que o âmbito académico, tal como o da circulação dos relatórios, era considerado de carácter tão restrito e tão longínquo das esferas da opinião pública, a ponto de permitir a expressão de divergências críticas? De notar, ainda, que a multiplicação dos estudos ditos científicos foi exponencial. Nomeadamente em áreas como a da religião, Salazar continuou a requerer ou a ser simplesmente informando dos estudos que continuavam a ser feitos. Foi o que sucedeu em início de 1960, quando Jorge Dias lhe enviou um exemplar dactilografado da sua conferência na Sociedade de Geografia de Lisboa, intitulado $O$ mundo sobrenatural dos indígenas na África portuguesa. Nele, o conhecido antropólogo continuou a recorrer à perspectiva valorizadora dos costumes próprios dos indígenas, especificando num tom generalizador que a «a ancestolatria é, portanto, o verdadeiro culto que conhecemos entre as populações indígenas». ${ }^{45}$

\section{Referências bibliográficas}

Alpers Edward

1984, "“To seek a better life": the implications of migration from Mozambique to Tanganyika for class formation and politicar behavior», Canadian Journal of African Studies, vol. 18, n. ${ }^{\circ}$ 2, pp. 367-388.

ARCHER Maria

1937, "Aspectos da "paisagem social” na África portuguesa e no Brasil do passado sugeridos pelos livros de Gilberto Freyre», Seara Nova, ano XVII, n. ${ }^{\circ}$ 536-537, pp. 166-170 e pp. 198-200.

BARros João de

1946, Presença do Brasil: páginas escolhidas 1912-1946. Lisboa, Edições Dois Mundos.

Barros João de; Oliveira José Osório de; Bettencourt Gastão de 1938, Brasil. Lisboa, Edições Europa.

45 ANTT, AOS/Co/Ul-37, Pasta 4, p. 15. Na mesma altura, Jorge Dias também enviou a Salazar o estudo de J. S. Bernardo Gonçalves, «Planificação e orientação do povoamento» (Maio de 1960). 
Bastos Cristiana; Almeida Miguel Vale de e Feldman-Bianco Bela (eds.)

2014 (2. ${ }^{\mathrm{a}}$ edição) [2002], Trânsitos coloniais: diálogos críticos luso-brasileiros. Lisboa, Imprensa de Ciências Sociais.

Bettencourt Gastão de

1954, Flagrantes de folclore do Brasil. Coimbra, Coimbra Editora.

Bon Antoine; Gautherot M. e Verger Pierre

1951-1952, Brésil. Prefácio de Alceu Amoroso Lima. Paris, Paul Hartmann; Livraria Agir.

BRÁsIo P. e António

1962, «Descobrimento, povoamento, evangelização do arquipélago de Cabo Verde», Stvdia (Lisboa), n. ${ }^{\circ}$ 10, Julho, pp. 49-62.

Brattain Michelle 2007, «Race, racism, and antiracism: Unesco and the politics of presenting science to the postwar public», The American Historical Review, vol. 112, n. ${ }^{\circ}$ 5, Dezembro, pp. 1386-1413.

CABral João de Pina e CARvalho Clara (eds.) 2004, A persistência da História: passado e contemporaneidade em África. Lisboa, Imprensa de Ciências Sociais.

CARvalho Clara

2004, «O olhar colonial. Fotografia e Antropologia no Centro de Estudos da Guiné Portuguesa», in Clara Carvalho e João de Pina Cabral (eds.), A persistência da história: passado e contemporaneidade em Africa. Lisboa, Imprensa de Ciências Sociais, pp. 119-145. 2008, "Raça”, género e imagem colonial: representações de mulheres nos arquivos fotográficos», in José Machado Pais, Clara Carvalho e Neusa Mendes de Gusmão (eds.), O visual e o quotidiano. Lisboa, Imprensa de Ciências Sociais, pp. 145-173.

Carvalho Rita 2005, «Vilhena, Ernesto Jardim de (1876-1967)», in Manuel Braga da Cruz e António Costa Pinto (eds.), Dicionário biográfico parlamentar 1935-1974, vol. II - (M-Z). Lisboa, Imprensa de Ciências Sociais; Assembleia da República.

CorrêA A. A. Mendes

1935, Cariocas e Paulistas. Impressões do Brasil. Porto, Fernando Machado \& Companhia.

1941, «Prefácio», in José Júlio Rodrigues, O Brasil... de relance. Porto, Editora Educação Nacional.

1945, O mestiçamento nas Colónias Portuguesas. Estudo apresentado ao II Congresso da União Nacional, em Maio de 1944. Lisboa, Agência Geral das Colónias. 
Curto Diogo Ramada e CRuz Bernardo Pinto da 2015, «Destribalização, regedorias e desenvolvimento comunitário: notas acerca do pensamento colonial português (1910-1965)», Práticas da História, Instituto de História Contemporânea, FCSH-UNL, n. ${ }^{\circ}$, pp. 113-172.

DiAs Jorge

1964, Os Macondes de Moçambique. Aspectos históricos e económicos - Estudo etnológico, vol. I. Lisboa, Junta de investigações do Ultramar.

Domingos Nuno

2009, «Minerva Central: uma Livraria Colonial», in Inês Brasão et al., Comunidades de leituras: Cinco estudos de Sociologia da Cultura. Lisboa, Colibri, pp. 63-120.

2015, "Colonial architectures, urban planning and the representation of portuguse imperial history », Portuguese Journal of Social Science, vol. $14,{ }^{\circ}{ }^{\circ}$ 3, pp. 235-255.

Domingos Nuno e Peralta Elsa (eds.)

2013, Cidade e Império: dinâmicas coloniais e reconfigurações pós-coloniais Lisboa, Edições 70 [«História e Sociedade»].

DutTon Geoffrey

1956, Africa in black and white. Prefácio de Roy Campbell. Londres, Chapman \& Hall.

FERreira Manuel

1986, «Prefácio - O fulgor e a esperança de uma nova idade», in Claridade. Revista de artes e letras [edição fac-similada]. Linda--a-Velha, Editor A.L.A.c., pp. XXIII-XXV.

FREYRE Gilberto

1940, O mundo que o português criou: aspectos das relações sociaes e de cultura do Brasil com Portugal e as colónias portuguesas. Rio de Janeiro, José Olympio Editora.

1951, Interpretação do Brasil: aspectos da formação social brasileira como processo de amalgamento de raças e culturas. Traduzido do inglês por Olívio Montenegro. Prefácio de José Osório Oliveira. Lisboa, Livros do Brasil.

1953, Aventura e rotina: sugestões de uma viagem à procura das constantes portuguesas de caráter e ação. Rio de Janeiro, Livraria José Olympio Editora.

Galvão Henrique e Selvagem Carlos

1952, Império Ultramarino Português. Monografia do Império, vol. III - Angola. Lisboa, Empresa Nacional de Publicidade. 
Gombrich E. H.

2002, The preference for the primitive. Episodes in the History of Western Taste and Art. Londres, Phaidon Press.

Havick Philip e Daveau Suzanne (eds.) 2010, Cadernos de campo Guiné 1947. Porto, Centro de Estudos Africanos; Húmus.

LEAL Cunha 1957, Coisas do tempo presente, vol. I - Coisas da Companhia de Diamantes de Angola (Diamang). Lisboa, Edição do Autor. 1959, Coisas do tempo presente, vol. II - Novas coisas da Companhia de Diamantes de Angola (Diamang). Lisboa, Edição do Autor. 1960 (2. ${ }^{a}$ edição), Coisas do tempo presente, vol. III - Peregrinações através do poder económico: novas peregrinações, diamanganas, deambulando por terras de Manica e Sofala, navegando nas albufeiras do Zêzere, digressão abissal pela Sonefe. Lisboa, Edição do Autor.

Lopes Baltasar

1956, Cabo Verde visto por Gilberto Freyre. Apontamentos lidos ao microfone de Rádio Barlavento. Praia, Imprensa Nacional.

2010, «Cabo Verde visto por Gilberto Freyre. Apontamentos lidos ao microfone de Rádio Barlavento», in Baltasar Lopes, Escritos filológicos e outros ensaios. Com biografia de Arnaldo França e estudo de Alberto Carvalho. Praia, Instituto da Biblioteca Nacional e do Livro, pp. 229-275.

LOPEs Edmundo Correia

1946, «Planos da psicologia nacional», Atlântico - Revista luso--brasileira, nova série, n. ${ }^{\circ} 7$, pp. 1-8.

Maio Marcos Chor 1999, «O projecto Unesco e a agenda das ciências sociais no Brasil dos anos 40 e 50», Revista Brasileira de Ciências Sociais, vol. 14, pp. 141-158.

MARGARIDO Alfredo 1972, «À propos d'un livre récent: mythes, légendes et objets plastiques dans l'histoire chokwe», Revue Française d'Histoire d'Outre-Mer, tome LIX, n. ${ }^{\circ}$ 216, pp. 491-504.

2001, "A impossibilidade portuguesa de reconhecer a importância estética das máscaras e das esculturas africanas», Latitudes, n. ${ }^{\circ}$ 13, Dezembro, pp. 3-11.

MENDEs Afonso 1965, Problemática do trabalho em África. Lisboa, Instituto Superior de Ciências Sociais e Política Ultramarina; Universidade Técnica de Lisboa. 


\section{Miceli Sérgio}

2012, Vanguardas em retrocesso: Ensaios de história social e intelectual do modernismo latino-americano. São Paulo, Companhia das Letras.

Molina António Muñoz

2014, «Um maestro dudoso», El País - Babelia, 12 Julho, p. 3 [Recensão de Rosa Sala Rose y Plàcid Garcia-Planas, El Marqués y la Esvástica. César González-Ruano y los judios en el París ocupado. Barcelona, Anagrama, 2014].

Moraes Marcos António de

2003, "Abrasileirar o Brasil" (Arte e literatura na epistolografia de Mário de Andrade)», Caravelle - Arts d'Amérique latine: marges et traverses, n. ${ }^{\circ}$ 8o, pp. 33-47.

Morais Coronel Alexandre de 1943, O Brasil de hoje, 2 volumes. Lisboa, Universo.

Neto Ana Maria 1991, Industrialização de Angola: reflexão sobre a experiência da administração portuguesa (1961-1975). Lisboa, Escher.

OliveIRa José Osório de 1926, Literatura brasileira. Prefácio de Carlos Malheiro Dias. Porto. Lúmen.

1933, Espelho do Brasil. Lisboa, Empresa Nacional de Publicidade.

1942, Enquanto é possível (Ensaios e outros escritos). Lisboa, Edições «Universo».

1943, Ensaístas brasileiros. Lisboa, Livraria Bertrand.

1944, Literatura africana. Lisboa, Agência Geral das Colónias. 1947, «No segundo aniversário da morte de Mário de Andrade», Atlântico - Revista luso-brasileira, nova série, n. ${ }^{\circ}$ 4, pp. 106-108 .

1949, «Os livros que nos deviam interessar», Atlântico - Revista luso-brasileira, $3 .^{\mathrm{a}}$ série, n. ${ }^{\circ} 1$.

1951, «Prefácio», in Gilberto Freyre, Interpretação do Brasil: aspectos da formação social brasileira como processo de amalgamento de raças e culturas. Lisboa, Livros do Brasil.

1952, Contribuição portuguesa para o conhecimento da alma negra. Lisboa, Tipografia Oficina Gráfica.

1954, Uma acção cultural em África. Lisboa, Tipografia Oficina Gráfica.

1956, «Novas considerações sobre o Museu do Dundo», in Quatro Ventos, separata. Braga, pp. 1-11. 
1956, «Da urgência do estudo da música negra», in Actas do $1 .^{\circ}$ Congresso de Etnografia e Folclore, vol. III. Lisboa, Plano de Formação Social e Corporativa, pp. 253-256.

1956, «Da necessidade dos museus africanos», in Actas do $1 .^{\circ}$ Congresso de Etnografia e Folclore, vol. III. Lisboa, Plano de Formação Social e Corporativa, pp. 439-444.

1957, «Epitáfio de Mário de Andrade [1945]», in O sonho inútil. Lisboa, Casa Portuguesa.

1958, Flagrantes da vida na Lunda. Lisboa, Companhia de Diamantes de Angola [ «Publicações Culturais», n. ${ }^{0}$ 37].

1960, «A máscara africana», A Ilha - Semanário cultural e informativo, 3 de Dezembro.

1961, "A máscara africana», in Tempo de exílio. Lisboa, Oficinas de Ramos, Afonso e Moita, pp. 65-68.

1962 (2. ${ }^{\text {a }}$ edição), Literatura africana. Lisboa, Sociedade de Expansão Cultural.

Oliveira José Osório de (ed.)

1946, «Cartas de Mário de Andrade», Atlântico - Revista lusobrasileira, nova série, $n .^{\circ}$, pp. 1-7.

OsóRIO João de Castro

1934, «Prefácio», in José Luiz Quintão, Gramática de Kimbundo. Lisboa, Edições Descobrimento.

1937, A formação orgânica da expansão portuguesa. Separata de 1. ${ }^{\circ}$ Congresso Nacional de História da Expansão Portuguesa no Mundo. Lisboa, Sociedade Nacional de Tipografia.

1938, Direito e dever do império. Lisboa, Edições Descobrimento.

\section{PEREIRA Rui}

1998, «Introdução", in Jorge Dias, Os Macondes de Moçambique. Lisboa, Comissão Nacional para as Comemorações dos Descobrimentos Portugueses; Instituto de Investigação Científica Tropical, pp. v-LII.

1938, «A emigração portuguesa para o Brasil», Seara Nova, ano XVIII, n. ${ }^{\circ}$ 576, pp. $275^{-277}$.

Pontes Heloísa

1995, «Brasil com Z: A produção estrangeira sobre o país, editada aqui, sob a forma de livro, entre 1930 e 1938», in Sérgio Miceli (ed.), História das ciências sociais no Brasil, vol. 2. São Paulo, Editora Sumaré, pp. 441-477. 
PORTO Nuno

1999, Angola a preto e branco. Fotografia e ciência no Museu do Dundo 1940-1970. Coimbra, Museu Antropológico da Universidade de Coimbra.

2009, Modos de objectificação da dominação colonial: o caso do Museu do Dundo, 1940-1970. Lisboa, Fundação Calouste Gulbenkian; Fundação para a Ciência e a Tecnologia.

QueIroz Carlos

1940, "Acerca da literatura moderna brasileira», Revista do Brasil, 3. ${ }^{\mathrm{a}}$ fase, ano III, n. ${ }^{\mathrm{o}}$ 25, Julho, pp. 54-56.

RodRigues José Júlio

1941, O Brasil... de relance. Prefácio do Doutor Mendes Corrêa. Porto, Editora Educação Nacional.

Rodrigues Comandante M. M. Sarmento

1952 (2. ${ }^{\mathrm{a}}$ edição), No Governo da Guiné. Lisboa, Agência Geral do Ultramar.

Roig Adrien

1979, «Une nouvelle "rencontre" Oswald de Andrade et Blaise Cendrars: interprétation du poème Morro Azul», Cahiers du monde hispanique et luso-brésilien, vol. 33, n. $^{\circ}$ 1, pp. 133-156.

1988, «Blaise de Cendrars et le Brésil: le grand film brésilien et la traduction de A Selva, le "Morro Azul" et la "Tour Eiffel sidérale" », in Portugal Brésil France. Actes du Colloque Paris, 25-27 mai 1987. Paris, Fondation Calouste Gulbenkian, 1988, pp. 273-298.

1988, La Fazenda São Martinho d'Oswald de Andrade et de Blaise Cendrars, separata de Quadrant. Montpellier, Université Paul Valéry, Centre de Recherche en Littérature en Langue Portugaise.

RoQue Ricardo

2001, Antropologia e Império: Fonseca Cardoso e a expedição à Índia em 1895. Introdução de Diogo Ramada Curto. Lisboa, Instituto de Ciências Sociais.

SÁ José Luís Pinto de

2006, Conquistadores de almas: Memórias de uma militância e prisões políticas (1970-1976). Lisboa, Guerra \& Paz.

SARAIVA Arnaldo

1986, O modernismo brasileiro e o modernismo português: subsídios para o seu estudo e para a história das suas relações. Porto, Edição do Autor.

SÉrgio António

1937, «Línguas brasileiras faladas e língua brasileira escrita, línguas 
portuguesas faladas e língua portuguesa escrita», Seara Nova, ano XVII, n. ${ }^{\circ}$ 525, pp. 403-410.

1940, «Prefácio», in Gilberto Freyre, O mundo que o português criou: aspectos das relações sociaes e de cultura do Brasil com Portugal e as colónias portuguesas. Rio de Janeiro, José Olympio.

Silva António Duarte 2010, Invenção e construção da Guiné-Bissau: Administração colonial, nacionalismo e constitucionalismo. Coimbra, Almedina.

Simões Nuno

1937, «A lição de São Paulo e o Ultramar Português (Carta a João Sarmento Pimentel)», Seara Nova, ano xvi, n. ${ }^{\circ} 496$.

1938, «Estudos brasileiros sobre problemas de alimentação», Seara Nova, ano XVIII, n. ${ }^{\circ} 573$, pp. 207-207.

1939, "Systema de colonização», Revista do Brasil, ano II, 3. ${ }^{\mathrm{a}}$ fase, n. ${ }^{\circ}$ 11, Maio, pp. 37-40.

STOckIng Jr. George W.

1991, "Maclay, Kubary, Malinowsky: Archetypes from the dreamtime of Anthropology», in George W. Stocking Jr. (ed.), Colonial situations: Essays on the contextualization of ethnographic knowledge. Madison, Wis., University of Wisconsin Press, pp. 9-74.

VALENTIM Carlos Manuel

2005, Avelino Teixeira da Mota - Ajudante de campo do Governador da Guiné Portuguesa. Lisboa, Academia de Marinha. 2007, O trabalho de uma vida. Biobibliografia de Avelino Teixeira da Mota (1920-1982). Lisboa, Edições Culturais da Marinha

VILHENA Ernesto

1955, Aventura e rotina (crítica de uma crítica). Lisboa.

WARNIER Raymond

182 1973, «Blaise Cendrars e o mundo luso-brasileiro», Colóquio Letras, n. ${ }^{\circ} 13$, Maio, pp. 15-31.

WEST Harry G.

2004, «Inverting the camel's hump: Jorge Dias, his wife, and I», in Richard Handler (ed.), Significant others: interpersonal and professional commitments in Anthropology. Madison, The University of Wisconsin Press, pp. 51-90.

2007, «Invertendo a bossa do camelo: Jorge Dias, a sua mulher, o seu intérprete e eu», in Manuela Ribeiro Sanches (ed.), Portugal 
não é um país pequeno. Contar o «império» na pós-colonialidade. Lisboa, Livros Cotovia, pp. 141-190.

\title{
XAVIER Sandra
}

2000, "Sobre "Angola a preto e branco: fotografia e ciência no Museu do Dundo 1940-1970" », Etnográfica, vol. Iv, n. ${ }^{\circ}$ 1, pp. 191-195.

\section{ZweIG Stefan}

1941, Brasil, país do futuro. Ensaio. Petrópolis.

Recepção do manuscrito: 09/02/2016

Conclusão da revisão: 27/05/2016

Aceite para publicação: 30/05/2016

Title: A photo album of Diamang

\begin{abstract}
Flagrantes da vida de Luanda (1958) by José Osório de Oliveira, a photographic album commissioned by the Diamond Company (Diamang), is the starting point for a discussion of colonial ideology. Following and discussing the descriptive method that anthropologists use, the proposed approach mobilizes a composite file comprised by diverse sources and documentary series. Likewise, analytical arguments are formulated, taking into account the need to distinguish between representations (produced with the intention of extracting from them a legitimizing effect of labor exploitation), and economic and political interests of those who could decide. Taken together, this is a dense description, but one that is capable of calling into question the perspectives that are too attentive to the cultural and aesthetic aspects of colonialism, which ultimately marginalize political and economic aspects.
\end{abstract}

Keywords: Colonial ideology, photography, detribalization, Lunda, Diamond Company, forced labor, modern slavery.

\section{Diogo Ramada Curto}

Historiador, é licenciado em História pela Faculdade de Letras da Universidade de Lisboa (1981) e doutorado em Sociologia Histórica (1995) pela Faculdade de Ciências Sociais e Humanas da Universidade Nova de Lisboa (FCSH-UNL), onde é professor desde 1981, e onde, em 1986, prestou provas de habilitação científico-pedagógica; é investigador do IPRI - Instituto Português de Relações Internacionais e coordenador do Grupo de Trabalho Modernidade Portuguesa e Sociologia Histórica Comparada. É bibliotecário da Casa Cadaval. As áreas fundamentais e principais interesses de investigação situam-se, actualmente, na história global, colonialismo, imperialismo, escravatura e História Cultural. Foi professor da Cátedra Vasco da Gama em História da Expansão 
Europeia no European University Institute, Florença, no período entre 2000 e 2008 e professor visitante em várias universidades (Brown e Yale, nos Estados Unidos da América; King's College-Londres, Inglaterra; EHEss - École des Hautes Études en Sciences Sociales, Paris, França).

Em 1998, co-fundou a colecção «Memória e Sociedade» (Difel), que dirigiu entre 1995 e 2005 e onde fez publicar dezenas de títulos; actualmente, co-dirige a colecção «História e Sociedade» (Edições 70), criada em 2010, e que, até ao momento já publicou cerca de meia centena de títulos de história e ciências sociais. É autor e organizador de cerca de cem artigos em revistas especializadas, em jornais, em capítulos de livros e de trinta livros, dentre os quais destacamos: Políticas coloniais em tempo de revoltas - Angola circa 1961 (Afrontamento, 2016); História política da cultura escrita: Estudos e notas críticas (Verbo, 2015); Para que serve a História? (Tinta da China, 2013); Cultura política no tempo dos Filipe, 1580-180o (Edições 70, 2011); A expansão marítima portuguesa, 1400-180o, org. com Francisco Bethencourt (Edições 70, 2010); As múltiplas faces da História (Livros Horizonte, 2008); Cultura escrita, séculos XV a XVIII (Imprensa de Ciências Sociais, 2007); Bibliografia da história do livro em Portugal (Biblioteca Nacional, 2005). Em 2013 ganhou o prémio Pen Clube de «Ensaio». É colaborador regular do jornal Público. Colaborou recentemente na Oxford History of Historical Writing, na Wiley-Blackwell Encyclopaedia of Empire, dirigida por John Mackenzie, e no Catálogo sobre Josefa de Óbidos do Museu Nacional de Arte Antiga.

[e-mail: dcur@fcsh.unl.pt] 